\title{
Site selection of mussel mitigation cultures in relation to efficient nutrient compensation of fish farming
}

\author{
Marie Maar ${ }^{1, *}$, Janus Larsen $^{1}$, Miriam von Thenen ${ }^{2,3}$, Karsten Dahl ${ }^{1}$ \\ ${ }^{1}$ Aarhus University, Department of Bioscience, Frederiksborgvej 399, PO Box 358, 4000 Roskilde, Denmark \\ ${ }^{2}$ Leibniz Institute for Baltic Sea Research Warnemünde, WG Marine Planning, Seestraße 15, 18119 Rostock, Germany \\ ${ }^{3}$ Aalborg University, Department of Planning, A. C. Meyers Vænge 15, 2450 Copenhagen, Denmark
}

\begin{abstract}
In the Baltic Sea, rainbow trout Oncorhynchus mykiss is the most common species used in marine aquaculture, but further increase in production is problematic due to environmental legal regulations, especially in the coastal zone. A solution could be to place the fish farms offshore and use mussel mitigation cultures to extract nutrients released from the fish farms. We used 3D ecological modeling to identify suitable locations for mussel mitigation cultures in relation to nutrient pollution from a fish farm in the inner Danish waters. The model results showed that potential mussel harvest depended on the food flux following a saturation curve with a maximum yield of 2100 to $2600 \mathrm{t}$ wet weight and then stabilized at around 2100 to $2600 \mathrm{t}$ wet weight of mussels. A single mussel farm ( $36 \mathrm{ha}$ ) can potentially remove $17-31 \%$ of the released nitrogen from the fish farm. Mussel farms located inside or a few $\mathrm{km}$ outside the coastal areas receiving the highest nutrient inputs from the fish farm were found to be the most suitable among the tested sites. In contrast, co-location with the fish farm was not advisable due to the negative benthic impact below the farms. However, it is up to the managers to decide which positive and negative effects should receive the most attention, given the present need for protection of water bodies and habitats and in relation to other activities in the area. This study demonstrates that modeling can support management decisions with respect to site selection of aquaculture and provide the needed data on far-field and local environmental effects from integrated aquaculture.
\end{abstract}

KEY WORDS: Integrated multi-trophic aquaculture $\cdot$ Rainbow trout $\cdot$ Mytilus edulis $\cdot$ Nutrient mitigation

\section{INTRODUCTION}

Aquaculture is a fast-growing sector, currently supplying half of the fish consumption worldwide (FAO 2016). Since the mid-1980s, catches from ocean fisheries have stagnated due to overfishing and depletion of fish stocks, and therefore the increasing demands for fish products must be sustained by aquaculture (Duarte et al. 2009). In the Baltic Sea, rainbow trout Oncorhynchus mykiss is the most common species used in marine aquaculture. Production began in the mid-1970s and increased rapidly during

\footnotetext{
${ }^{*}$ Corresponding author: mam@bios.au.dk
}

the 1980s until it reached an annual production of 21 000-26 000 t in the 1990s (Fig. 1). Since then, production has declined in Sweden, Finland and Germany, whereas Denmark has been the only country with increasing production. The main producers today are Denmark and Finland, each with an annual production of $12000 \mathrm{t}$ (Fig. 1). Further expansion of the aquaculture sector in the Baltic Sea is problematic due to environmental legal regulations, absence of political support on the national level, undeveloped marine spatial planning and time-consuming permit applications (Bostock et al. 2010, Kotta et al.

() The authors 2020. Open Access under Creative Commons by Attribution Licence. Use, distribution and reproduction are unrestricted. Authors and original publication must be credited. 


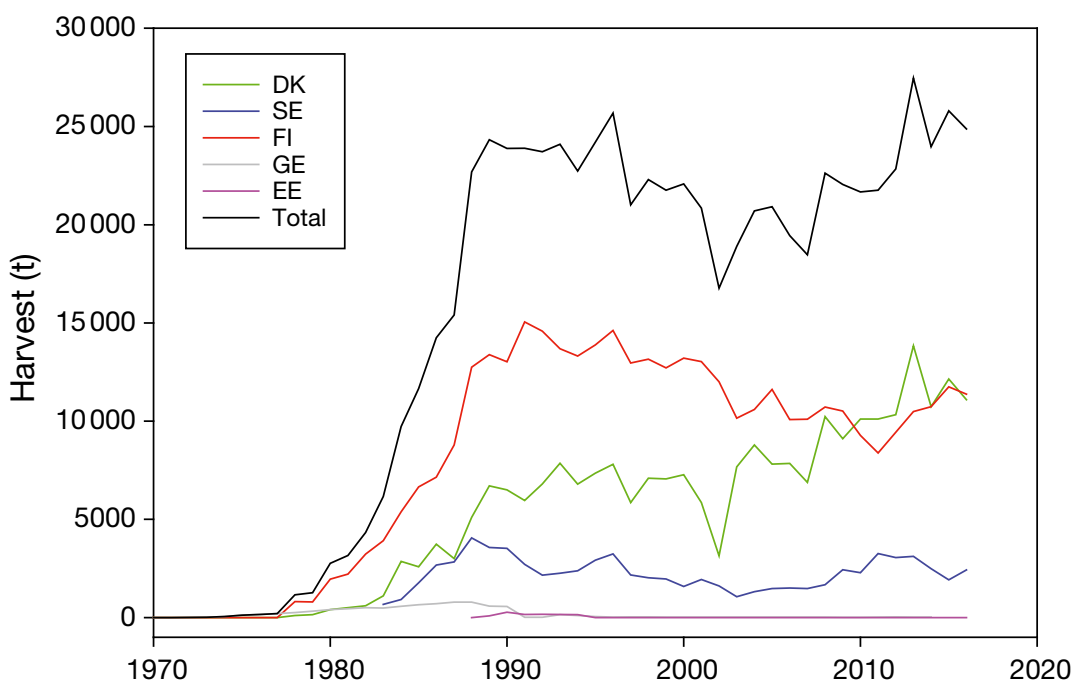

Fig. 1. Annual harvest of rainbow trout from marine aquaculture over time in the Baltic Sea. DK: Denmark; SE: Sweden; FI: Finland; GE: Germany; EE: Estonia

2020). In Denmark, a recent law from 2017 enacted by the Ministry of Environment and Food allowed finfish aquaculture to expand on the condition that measures to compensate for the extra nutrient loads are included, e.g. long-line production of blue mussels (LOV nr. 680 af 08/06/2017). However, the government has now put the law on hold, and new aquaculture units have not yet been approved. Nevertheless, there is still a strong desire from the aquaculture sector to expand production, and more research is needed to investigate the possibilities of using compensating measures in the future.

The Baltic Sea is characterized as eutrophic in most areas, and further nutrient reductions are needed to improve the ecosystem health (HELCOM 2013, Maar et al. 2016). The inner Danish waters are no exception, and hypoxia events have been occurring every summer in the deeper areas (Conley et al. 2007, Riemann et al. 2017). Fish farms are polluting the environment with nutrients through biodeposition of excess fish feed and feces, which may alter the biogeochemical cycle and oxygen conditions of the sediments (Christensen et al. 2000, Tovar et al. 2000). Further, dissolved nutrients are excreted by the fish and may promote primary production, which is nutrientlimited during summer (Maar et al. 2018a). The increased primary production can lead to elevated phytoplankton biomass and reduced water clarity, which ultimately will reduce the benthic vegetation (Dalsgaard \& Krause-Jensen 2006).

The future fish farms in Denmark are planned to be placed in open waters, i.e. $>1$ nautical mile (n mile) from land, and hence outside the administrative coastal areas protected by the EU Water Framework Directive (WFD; Directive 2000/60 EC). In addition, the farms should be located a safe distance from marine protected areas (MPAs) according to the EU Habitats Directive (Habitats Directive (92/43/EEC REF). If some of the nutrients (either the inorganic pool or bound, e.g. in phytoplankton biomass) released from the fish farms are advected into the coastal water areas, it may violate the goal of the WFD to achieve a good environmental status (Wild-Allen et al. 2010, Maar et al. 2018a) or the goal to reach good conservation status in the MPA. Previous model studies showed that the amount of nutrients transported into the coastal water areas was around $20 \%$ from potential fish farms located in the Samsø Belt (Maar et al. 2018a) and $38-57 \%$ from those located in the Kattegat, varying with distance to the coast and current directions (Kaas et al. 2017). Hence, it is important to compensate the nutrient-affected coastal water areas using marine measures (e.g. blue mussel mitigation cultures) assuring an efficient nutrient removal and minimum impact on ecosystem functions (Maar et al. 2018a, Kotta et al. 2020).

Integrated multi-trophic aquaculture (IMTA) is the co-culturing of different species that can be used to reduce the nutrient emission from e.g. fish farms. The concept of IMTA uses a nutrient cycling approach between trophic levels, where the dissolved or solid nutrient input from one species (e.g. fish) is utilized by the extractive species (e.g. seaweeds, mussels) and removed from the system through harvesting (Chopin et al. 2012). However, mussels capture nutrients in particulate form, primarily as phytoplankton, and not directly the dissolved nutrients released from the fish farm. In addition, the waste particles are inaccessible to mussels due to the high settling velocity of the major part of the particles (Reid et al. 2009, Cranford et al. 2013). For the remaining smaller particles, the short residence time of the particles inside the mussel farm reduces mussel removal potential (Cranford et al. 2013, Filgueira et al. 2017). Hence, the mitigation of nutrient release from a fish farm in IMTA farms works on the mass balance principle on a basin scale, and not as a measure to specifically remove the $\mathrm{N}$ and $\mathrm{P}$ molecules released from the fish farm (Cranford et al. 2013, Sanz-Lazaro \& SanchezJerez 2017). One option is to place the mussel farms 
in open waters either co-located with the fish farm or in the main downstream current direction, thereby assuming that most of the nutrients are removed in the open waters and not transported into the coastal waters. Another option is to place the mussel farms in the WFD area affected by nutrient transports from the fish farm and only compensate for the fraction of the released nutrients entering the area. This approach would require model estimates of the farfield nutrient transports from the fish farm.

In addition, the mussel mitigation farms themselves have environmental impacts, positive as well as negative ones. Mussel farms can positively impact the environment through filtration of particles (mainly phytoplankton biomass), leading to lower chlorophyll a (chl a) concentrations and improved water clarity (Schröder et al. 2014, Timmermann et al. 2019). However, increased bio-deposition below the mussel farm increases organic enrichment on the seabed, leading to hypoxia and changes in nutrient cycling (Petersen et al. 2019a). Hence, the optimal sites for nutrient mitigation in relation to fish farms depend on the physical dispersion of nutrients and the associated biogeochemical processes in the water column as well as in the sediment. The outcome of these processes can be evaluated using 3D coupled hydrodynamic-ecological models (Filgueira et al. 2017, Maar et al. 2018a). The aim of the present study was to use an ecological model to identify suitable locations for mussel mitigation cultures in relation to nutrient pollution from a fish farm, taking into account both nutrient removal efficiency and environmental effects of each mussel farm in its particular location.

\section{MATERIALS AND METHODS}

\subsection{Study area and location of fish farms}

The Samsø Belt is located between the Kattegat, the Great Belt and the Little Belt in Denmark (Fig. 2). The system is affected by eutrophication, and summer primary production is mainly N-limited (Carstensen et al. 2004). In a previous study, 2 rainbow trout farms were artificially launched in the model at 2 locations suggested by the aquaculture producers (Maar et al. 2018a). In the present study, we only considered the northern farm located in the water area called 'Ballen' with a water depth of 19-20 m, which is close to a coastal water area (Samsø, Fig. 2). In Danish estuaries and coastal waters, the epibenthic blue mussels Mytilus edulis and the infauna soft-shell clams Mya arenaria and cockles (Cardium spp.) are important benthic filtrators (Conley et al. 2000). Blue mussel larvae are mainly present during spring in the study area, and observations suggest that larvae densities are sufficient for successful recruitment of new mussel farms (Riisgård et al. 2015).

\subsection{Model system}

The biogeochemical model was coupled to a 3D offline advection module in the FlexSem framework using an unstructured computational mesh for the Samsø Belt (Petersen et al. 2017, Larsen et al. 2020). The offline advection module was implemented on a horizontal grid with rectangular cells $(1800 \times 1800 \mathrm{~m})$ and used current velocity data from the year 2009 from the 3D ocean circulation Hiromb-BOOS model (Berg \& Poulsen 2012). The unstructured mesh approach allowed a gradual refinement of the computational mesh around the fish farm $(6 \times 12$ grid cells $)$, where the horizontal resolution of the larger cells was increased to $600 \times 600 \mathrm{~m}$ and further to $200 \times 200 \mathrm{~m}$ near the fish farm. The separation between computational cells in the vertical was defined at fixed depths, whereas the top layer had a free surface to allow for water level changes. The layer thickness was set to $2 \mathrm{~m}$ in the top layer, followed by $1 \mathrm{~m}$ in the upper $30 \mathrm{~m}$ and $10 \mathrm{~m}$ in the bottom cell from 31-40 m depth. Further details of the physical model set-up and mesh can be found in Maar et al. (2018a).

\subsection{Ecological model}

The biogeochemical model ERGOM (Neumann 2000, Maar et al. 2011, Wan et al. 2012) simulates the cycling of N, P and silicon (Si). The 11 state variables describe concentrations of 4 dissolved nutrients $\left(\mathrm{NO}_{3}\right.$, $\mathrm{NH}_{4}, \mathrm{PO}_{4}, \mathrm{SiO}_{2}$ ), 3 functional groups of phytoplankton (diatoms, flagellates, cyanobacteria), micro- and mesozooplankton, detritus and oxygen (Fig. 3). The model considers the processes of nutrient uptake, $\mathrm{N}_{2}$ fixation by cyanobacteria, growth, grazing, respiration, recycling, mortality, settling, nitrification and denitrification. The pelagic ERGOM model is 2-way coupled to a sediment biogeochemical model through sedimentation and resuspension of organic matter and diffusive fluxes of nutrients and oxygen (Petersen et al. 2017). Pelagic detritus and diatoms sediment into an organic detritus pool and a dead diatom pool, respectively, in the unconsolidated top layer of the sediment (Fig. 3). Organic matter in the unconsolidated sediment can be resuspended, respired or 

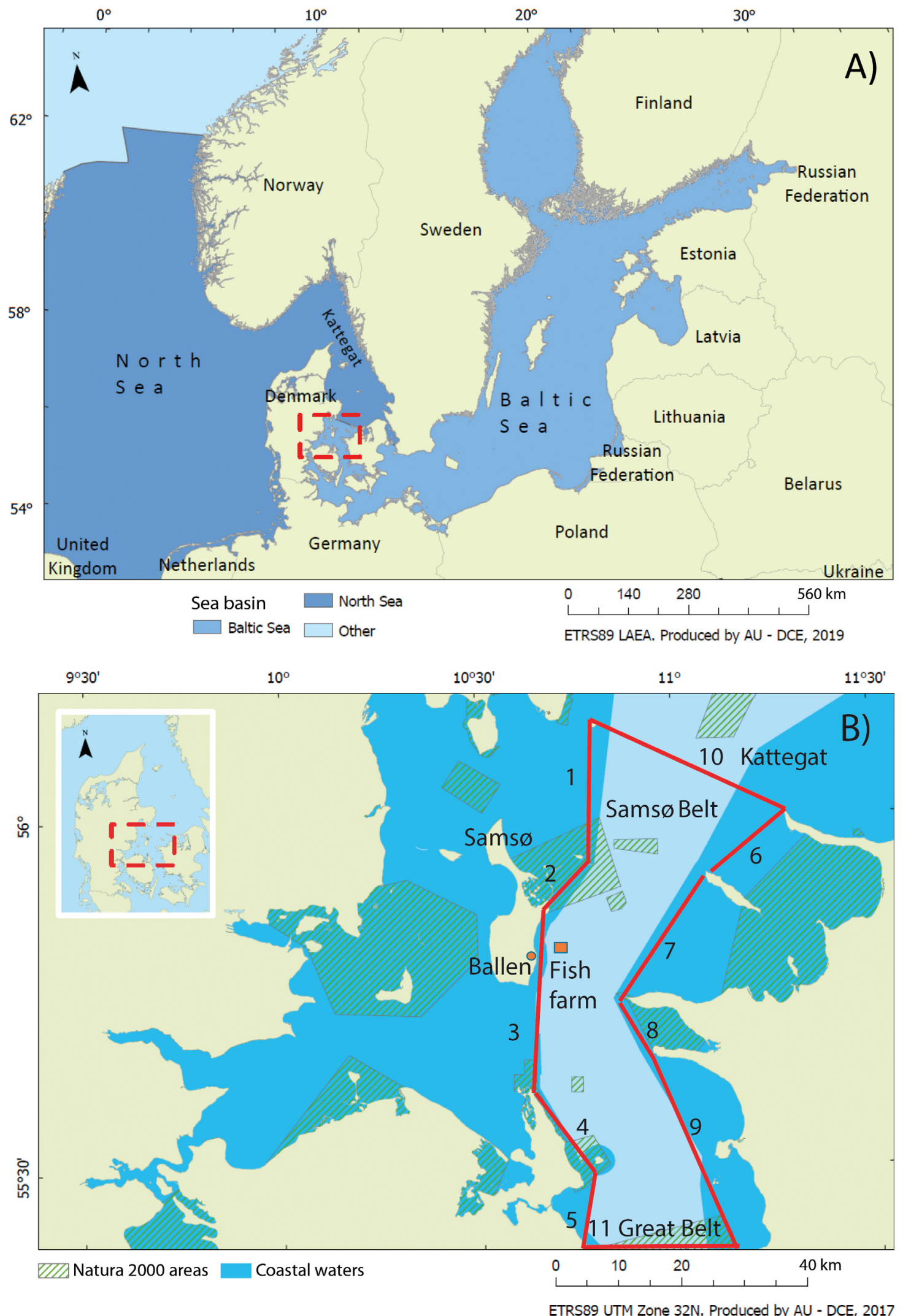

Fig. 2. (A) Study site (outlined in red) in the Danish transition area between the North Sea and the Baltic Sea. (B) Location of the fish farm in the open waters of the Samsø Belt area and the neighboring EU Water Framework Directive (WFD) coastal waters and Natura 2000 areas. The 11 transects for estimations of nutrient transport are shown as red lines with numbers. The dark blue area indicates the administrative coastal areas protected by the WFD and the light blue area is defined as open water 


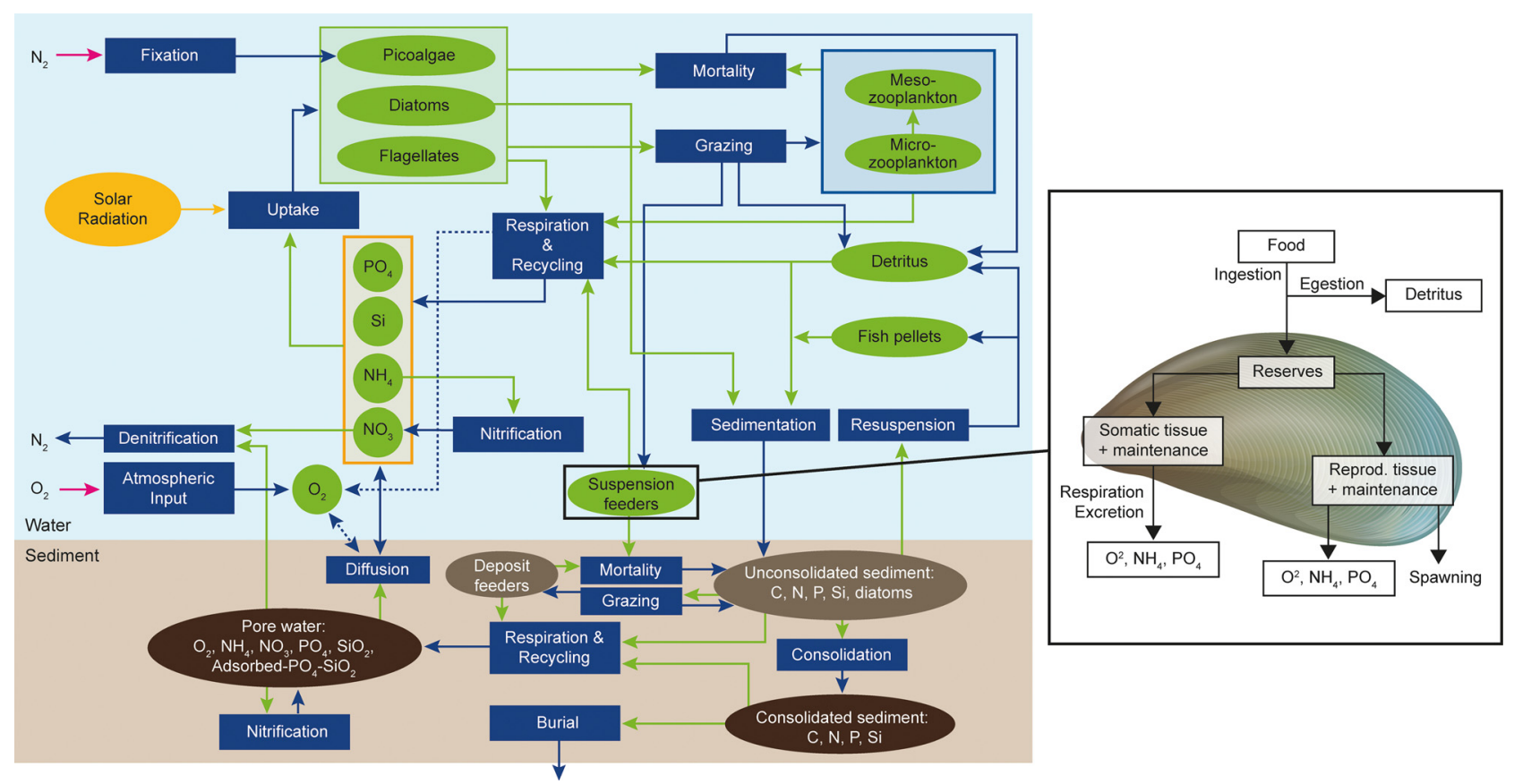

Fig. 3. Pelagic (green) and benthic (brown) state variables and associated fluxes (blue) in the biogeochemical ERGOM model. Suspension feeders are described in more detail as blue mussels using a dynamic energy budget model combined with a population model for the long-line mussel farms at 0-6 m depth. Modified from Maar et al. (2018a)

gradually transferred to the consolidated sediment layer. Recycled nutrients $\left(\mathrm{NH}_{4}, \mathrm{PO}_{4}\right.$ and $\left.\mathrm{SiO}_{2}\right)$ in the sediment porewater are exchanged with the bottom water through diffusion, and a fraction of the recycled $\mathrm{NH}_{4}$ is lost in a coupled nitrification-denitrification process. Under oxidized conditions, $\mathrm{PO}_{4}$ and $\mathrm{SiO}_{2}$ are retained in the sediment by adsorption to iron or manganese, and are released when the sediment becomes reduced. Benthic suspension feeders ingest phytoplankton, detritus and biodeposits from IMTA farms in the bottom water, whereas deposit feeders ingest freshly deposited diatoms, detritus and biodeposits from the IMTA farms in the sediment. The pelagic and benthic model parts were previously validated (Maar et al. 2011, 2016, 2018a, Petersen et al. 2017).

\subsection{Fish farm}

The potential fish farm in the model is placed offshore of the village 'Ballen', i.e. $>1 \mathrm{n}$ mile from land outside the administrative coastal water areas (Fig. 2). The farm area was $0.36 \mathrm{~km}^{2}(600 \times 600 \mathrm{~m}, 9$ grid cells) and extended to $10 \mathrm{~m}$ depth. The fish production season was from April to November, with a seasonal dome-shaped waste production since the fish stock is low at the beginning of the season, increases during the summer period and requires less food for growth at the end of the season (Nielsen et al. 2015). The fish farm can produce $2200 \mathrm{t}$ finfish, and the waste is $100 \mathrm{t} \mathrm{N}$ and $12.8 \mathrm{t} \mathrm{P}$ per productive season (Dalsgaard \& Pedersen 2016). Total waste from rainbow trout is separated into solid matter $(16 \% \mathrm{~N}, 56 \%$ $\mathrm{P})$ and dissolved fractions $\left(\mathrm{NH}_{4}, \mathrm{PO}_{4}\right)$ and added as a source to the model. The settled solid waste (fish feces and uneaten feed) was assumed to immediately settle at the bottom, from where it can be resuspended, degraded or gradually transferred to the consolidated sediment layer (Maar et al. 2018a). After resuspension, the solid fish waste is assumed to be fragmented into smaller particles with a sinking velocity of $0.03 \mathrm{~cm} \mathrm{~s}^{-1}$, which allows dispersal of the waste outside the fish farm area. The solid fish waste was included as 3 new benthic state variables $(C, N$, $P)$ and 3 new pelagic state variables $(C, N, P)$ with variable nutrient ratios (Fig. 3). The nutrients excreted as dissolved fractions from mussel and fish farms or remineralized from the waste can be taken up by the phytoplankton and support primary production in the ecological model.

\subsection{Mussel mitigation cultures}

The mussel farm covered the same area of $0.36 \mathrm{~km}^{2}$ (36 ha) as the fish farm, corresponding to the size of 
2 standard mussel farms with vertical mussel loops attached to long-lines (Nielsen et al. 2016). The depth range of the mussel loops can be adjusted according to the water depth and, in the present study, ranged from 0 to $6 \mathrm{~m}$ below the surface. The mussel farm started to operate from 1 July in the model after self-recruiting of mussel larvae. The initial abundance of mussels was 52070 ind. $\mathrm{m}^{-1}$ of substrate (first observation from 14 July by Nielsen et al. 2016). Abundance decreased exponentially with shell length in the model due to detachment as the mussels grew larger and space became limiting (Nielsen et al. 2016). Other mortality sources such as bird predation (e.g. eiders) were not considered due to lack of knowledge of their potential occurrence and impact. The initial shell length was $0.62 \mathrm{~cm}$, and 1 cohort of mussels was followed over time (Nielsen et al. 2016). Harvest was assumed to take place on 1 December to avoid damage from ice cover and storms during winter (Taylor et al. 2019). A dynamic energy budget (DEB) model was used to describe the growth of individual mussels within the cohort in response to temperature, salinity and food concentrations (Maar et al. 2015). The DEB model was originally developed by Kooijman (2010) and has been applied to a wide range of bivalves (van der Veer et al. 2006), including Danish blue mussels (Maar et al. 2009). The mussel model for 1 cohort was coupled to the ecological model through ingestion of phytoplankton biomass and detritus, excretion of nutrients fueling primary production, respiration and biodeposition of fecal material using the Redfield ratio for conversion from $\mathrm{N}$ to $\mathrm{P}$ and $\mathrm{Si}$ (Fig. 3). There was a lower preference and assimilation efficiency of detritus compared to phytoplankton biomass. Hence, the mussels could not directly utilize the inputs of inorganic dissolved nutrients from the fish farm, but removed nutrients bound in phytoplankton biomass and detritus by filtration and incorporated the ingested nutrients into mussel biomass. The incorporated nutrients through ingestion are not only found in mussel meat, but around 40 and $4 \%$ of the total bounded N and P, respectively, are found in shell and byssus (Petersen et al. 2014). The mussel shell is synthesized from both dissolved inorganic carbon in the water and organically derived $\mathrm{CO}_{2}$ from respiration (Lorrain et al. 2004). Hence, we assumed that a fraction of the respired $\mathrm{N}$ was built into the shell and byssus instead of being excreted ( $\mathrm{P}$ in the shell was ignored) and that there was no loss of $\mathrm{N}$ from the shell. The N-fraction for shell growth was estimated by model calibration. Dry weight (DW) of the mussel tissue was converted to wet weight (WW) of the whole mussel (with shell) using a conversion factor of $0.1 \mathrm{~g} \mathrm{DW} / \mathrm{g}$ WW (Nielsen et al. 2016).

\subsection{Scenarios with mussel mitigation farms}

The reference run (REF) was conducted without the fish farm and mussel farms, and scenario 'S100' included only the Ballen fish farm with a nitrogen input of $100 \mathrm{t} \mathrm{N}$ (Table 1); both set-ups were identical to the model runs described by Maar et al. (2018a). The main surface current direction was northerly $\left(0-25^{\circ}\right)$ and to a lesser extent southerly, whereas bottom cur-

Table 1. Overview of the scenarios with different farm locations indicated with the distance to the fish farm and to nearest land, main current direction and water depth

\begin{tabular}{|c|c|c|c|c|c|c|c|}
\hline Scenario & Description & $\begin{array}{l}\text { Fish } \\
\text { farm }\end{array}$ & $\begin{array}{l}\text { Mussel } \\
\text { farm }\end{array}$ & $\begin{array}{l}\text { Distance to } \\
\text { fish farm (km) }\end{array}$ & $\begin{array}{l}\text { Distance to land } \\
\qquad(\mathrm{km})\end{array}$ & $\begin{array}{c}\text { Main surface } \\
\text { current direction }\end{array}$ & $\begin{array}{l}\text { Water depth } \\
\text { (m) }\end{array}$ \\
\hline REF & Reference scenario & $x$ & $x$ & - & - & & \\
\hline S100 & Ballen fish farm & $\checkmark$ & $x$ & 0.0 & 4.8 & NNE & 20 \\
\hline \multicolumn{8}{|c|}{ Open waters } \\
\hline M0 & Co-location & $\checkmark$ & $\checkmark$ & 0.0 & 4.8 & NNE & 20 \\
\hline M1 & NE from fish farm & $\checkmark$ & $\checkmark$ & 5.7 & 3.6 & $\mathrm{NE}$ & 21 \\
\hline M2 & NNE from fish farm & $\checkmark$ & $\checkmark$ & 3.0 & 3.2 & NNE & 18 \\
\hline M3 & $\mathrm{W}$ of fish farm & $\checkmark$ & $\checkmark$ & 1.8 & 2.4 & NNE & 18 \\
\hline M4 & SSW from fish farm & $\checkmark$ & $\checkmark$ & 3.0 & 5.9 & $\mathrm{~N}$ & 18 \\
\hline M5 & SW from fish farm & $\checkmark$ & $\checkmark$ & 5.1 & 2.4 & $\mathrm{~N}$ & 19 \\
\hline \multicolumn{8}{|c|}{ Coastal waters } \\
\hline $\mathrm{C} 1$ & NW of fish farm & $\checkmark$ & $\checkmark$ & 4.7 & 0.6 & $\mathrm{NE}$ & 9 \\
\hline $\mathrm{C} 2$ & W of fish farm & $\checkmark$ & $\checkmark$ & 3.6 & 0.6 & NNE & 11 \\
\hline C3 & W of fish farm & $\checkmark$ & $\checkmark$ & 3.6 & 0.6 & $\mathrm{~N}$ & 20 \\
\hline $\mathrm{C} 4$ & SW of fish farm & $\checkmark$ & $\checkmark$ & 6.0 & 0.9 & NE & 20 \\
\hline
\end{tabular}


rents moved in both southwesterly and northeasterly directions due to tidal influence (Maar et al. 2018a). In the present study, surface averages (July to November) of current speed, chl a concentration and food flux to the mussel farms during the fish farm production period were estimated from the model data in the study area. The food flux ( $F F, m g ~ c h l ~ a ~ m^{-2} \mathrm{~s}^{-1}$ ) was obtained from the current speed $\left(V, \mathrm{~m} \mathrm{~s}^{-1}\right)$ and

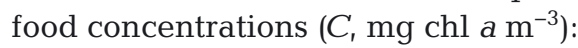

$$
\mathrm{FF}=V \times C
$$

A higher food flux to the mussel farm was expected to yield a higher mussel biomass. The combination of current directions and food fluxes was used to choose 10 potential sites for mussel mitigation cultures around the fish farm (Table 1, Fig. 4C). For open waters, a mussel farm was placed at 6 different locations in scenarios M0-M5 to test whether co-location with the fish farm (M0), locations in the main current directions close to the fish farm (M2 and M4), in high food flux areas (M1) or close to the nearest coastal area (M3 and M5) would have the highest impact on the nutrient removal, nutrient transports and environmental effects. The first mussel farm was colocated with the fish farm (M0). Mussel farm M1 was placed furthest away (5.7 km NE) from the fish farm towards the Kattegat, coinciding with the highest current speeds and food flux in the area. Two farms were placed in the 2 main surface current directions towards the north (M2) and south (M4) with a distance of $3.0 \mathrm{~km}$ from the fish farm. Mussel Farm M3 was placed $1.8 \mathrm{~km}$ west of the fish farm and Farm M5 was placed $5.1 \mathrm{~km}$ SSW from the fish farm in order to filter nutrients going directly towards the nearest coastal area outside Samsø (both $2.4 \mathrm{~km}$ from land). For the nearby coastal waters, 4 mussel farms (scenarios C1-C4) were placed along the coastline of Samsø following a food flux gradient and with 3.6-6.0 $\mathrm{km}$ distance from the fish farm (Table 1, Fig. 4C). The average conditions in Fig. 4 were used to identify potential sites for mussel farms, whereas the actual food fluxes and associated mussel growth were estimated dynamically for each time-step when running the model scenarios for each farm location.

For each scenario, the gross $\mathrm{N}$ and $\mathrm{P}$ transports across the 11 transects shown in Fig. 2 were calculated. The transects followed the borders between open waters and coastal areas (Transects 1-9) or the entrance to the neighboring open-water areas (Transects 10 and 11). Transects 1-5 were grouped as 'western coastal areas,' Transects 6-9 were grouped as 'eastern coastal areas,' Transect 10 represented the transport to the Kattegat/North Sea, and Transect 11 represented the transport to the Great Belt/Baltic Sea. All transports were estimated as the difference relative to the reference run (without fish and mussel farms). Total WW (t) of mussel biomass per farm and total $\mathrm{N}$ removal (tissue and shell) were estimated for each scenario. $\mathrm{P}$ removal was estimated from $\mathrm{N}$ removal in mussel tissue (no shell) using the Redfield ratio.

The uncertainty related to the mussel production estimated by the DEB model was assessed by changing the half-saturation coefficient, $X_{\mathrm{k}}$, in the mussel ingestion response. $X_{\mathrm{k}}$ is known to be site specific due to different food composition and quality and often needs to be re-calibrated (Bacher \& Gangnery 2006). In a previous study of oyster growth, the range of $X_{\mathrm{k}}$ values varied $\pm 32 \%$ around the mean value from 16 sites (Bacher \& Gangnery
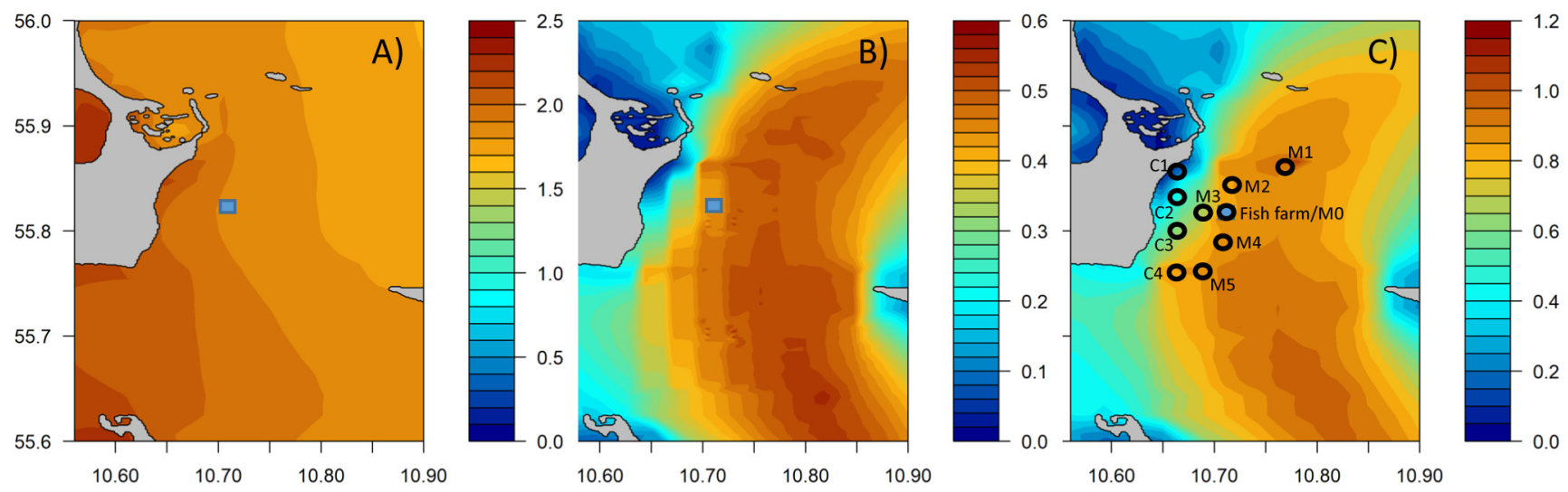

Fig. 4. Average surface (A) chl a concentration $\left(\mathrm{mg} \mathrm{m}^{-3}\right)$, (B) current velocity $\left(\mathrm{m} \mathrm{s}^{-1}\right)$ and (C) food flux (mg m $\left.{ }^{-2} \mathrm{~s}^{-1}\right)$ from July to November 2009. The blue box marks the location of the fish farm and the black circles show the locations of potential mussel farms (C: coastal, M: open water) 
2006). We therefore changed the $X_{\mathrm{k}}$ accordingly in the DEB model for each farm location to give a possible range of outcomes of harvested mussel biomass and nutrient removal. The effects of mussel filtration on Secchi depth, chl a concentrations, primary production, surface nutrient concentrations and bottom oxygen were estimated for the mussel farm area $(600 \times 600 \mathrm{~m})$ from July to November. Further, changes in surface chl a concentrations were estimated spatially for the Samsø Belt area. For the sediment impact, the accumulation of organic matter, denitrification and other nutrient fluxes were estimated beneath the mussel farms $(600 \times 600 \mathrm{~m})$ from April to December.

In order to discuss optimal site selection for mussel mitigation cultures, the farms were ranked according to their nutrient removal efficiency ( $\mathrm{N}$ removed by harvest), nutrient transport reduction to the nearby western coastal area, surface chl a concentration, Secchi depth, denitrification, surface dissolved inorganic nitrogen (DIN) concentration, sediment organic $\mathrm{N}$ content, $\mathrm{NH}_{4}$ fluxes and oxygen uptake by the sediment. The first 5 mentioned effects were considered as positive and the last 4 as negative effects on the system. The system is $\mathrm{N}$ limited, so P concentrations and fluxes were ignored. The values were normalized by the maximum value for each effect to provide a ratio between 0 and 1 (where 1 indicates the highest impact). In order to compare negative and positive effects on the same scale, the ratio was converted to ' 1 - value/max' for the negative effects to ensure that the worst performance was equal to the lowest ratio and vice versa. For simplification of the comparison, a ratio $<0.33$ was colored red (poor performance), ratios of $0.33-0.66$ were colored orange (medium performance), and a ratio $>0.66$ was colored green (best performance). The overall ranking for all effects was not estimated, because it is a management decision how to weight the effects against each other under the given environmental conditions.

\section{RESULTS}

\subsection{Food flux, mussel growth and $\mathrm{N}$ removal}

In the Samsø Belt area, chl a concentrations showed a spatial gradient, with the lowest values $\left(1.7 \mathrm{mg} \mathrm{m}^{-3}\right)$ in the NE part and the highest values $\left(2.5 \mathrm{mg} \mathrm{m}^{-3}\right)$ in the SW part during the mussel production period from July to November (Fig. 4A). Average surface currents (April to November) were lowest along the coastlines, around $0.02 \mathrm{~m} \mathrm{~s}^{-1}$, and increased gradually towards the open waters up to $0.66 \mathrm{~m} \mathrm{~s}^{-1}$ (Fig. 4B). The estimated food fluxes mainly followed the pattern of surface currents, with the lowest values at the coastline and gradual increases towards open waters up to $1.2 \mathrm{mg} \mathrm{chl} \mathrm{a} \mathrm{m} \mathrm{m}^{-2} \mathrm{~s}^{-1}$ (Fig. 4C). Seasonal growth of mussels was highest during autumn, and biomass stagnated or even decreased in November before harvest (Fig. 5A). At harvest, the obtained shell length varied from $2.3 \mathrm{~cm}$ in scenario $\mathrm{C} 1$ to 3.0 $\mathrm{cm}$ at C4 (Fig. 5B). Harvested mussel biomass varied from 1293 to $2579 \mathrm{t} \mathrm{WW}$ at the 10 farm locations, with the lowest biomass in $\mathrm{C} 1$ and highest in C4 (Table 2). Location $\mathrm{C} 1$ also had the lowest food flux, whereas C4 did not have the highest food flux as expected from the highest mussel biomass. Both $\mathrm{C} 1$ and $\mathrm{C} 4$ had the highest chl a concentrations among the locations (Table 2). Total $\mathrm{N}$ removal per mussel farm showed a saturation response with increasing food flux and up to $30.9 \mathrm{t} \mathrm{N}$ removal per farm in $\mathrm{C} 4$ (Fig. 6A). The $\mathrm{N}$ removal of the coastal farms increased with increasing food flux, whereas the open water stations showed a similar $\mathrm{N}$ removal above

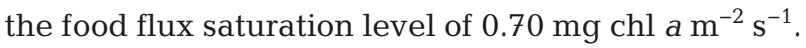
$\mathrm{P}$ removal ranged from $1.46 \mathrm{t}(\mathrm{C} 1)$ to $2.90 \mathrm{t} \mathrm{P}(\mathrm{C} 4)$ per farm and showed the same response as for $\mathrm{N}$ (Fig. 6A). All farms, except C1, performed well (ratio $>0.66$ ) in the ranking between farms (Table 3 ). The estimated harvested mussel biomass and nutrient removal showed highest increases of $11-31 \%$ from the mean if the $X_{\mathrm{k}}$ was set to the minimum value (Table 2). The response was slightly lower when applying the maximum $X_{\mathrm{k}}$ value, which resulted in 9-20\% lower mussel harvest and nutrient removal (Table 2).

\subsection{Transports of nutrients}

The gross transport of $\mathrm{N}$ and $\mathrm{P}$ from the fish farm (S100) was highest to the western coastal areas, followed by the North Sea, the eastern coastal areas and finally the Baltic Sea (Fig. 6C-F). N and P transport to all neighboring water areas was highly reduced when introducing mussel farms at various locations together with the fish farm (Fig. 6B, Table 4). The highest reduction across all transects was found for $\mathrm{C} 4$ and the lowest for $\mathrm{C} 1$. For the western coastal areas (Transects 1-5), the N transport was significantly reduced from $16.4 \mathrm{t}$ in $\mathrm{S} 100$ to 5.8-9.8 t N with increasing $\mathrm{N}$ removal in the mussel farm scenarios (Fig. 6C). However, the obtained correlation $\left(\mathrm{R}^{2}=0.64\right)$ was lower than for the east- 

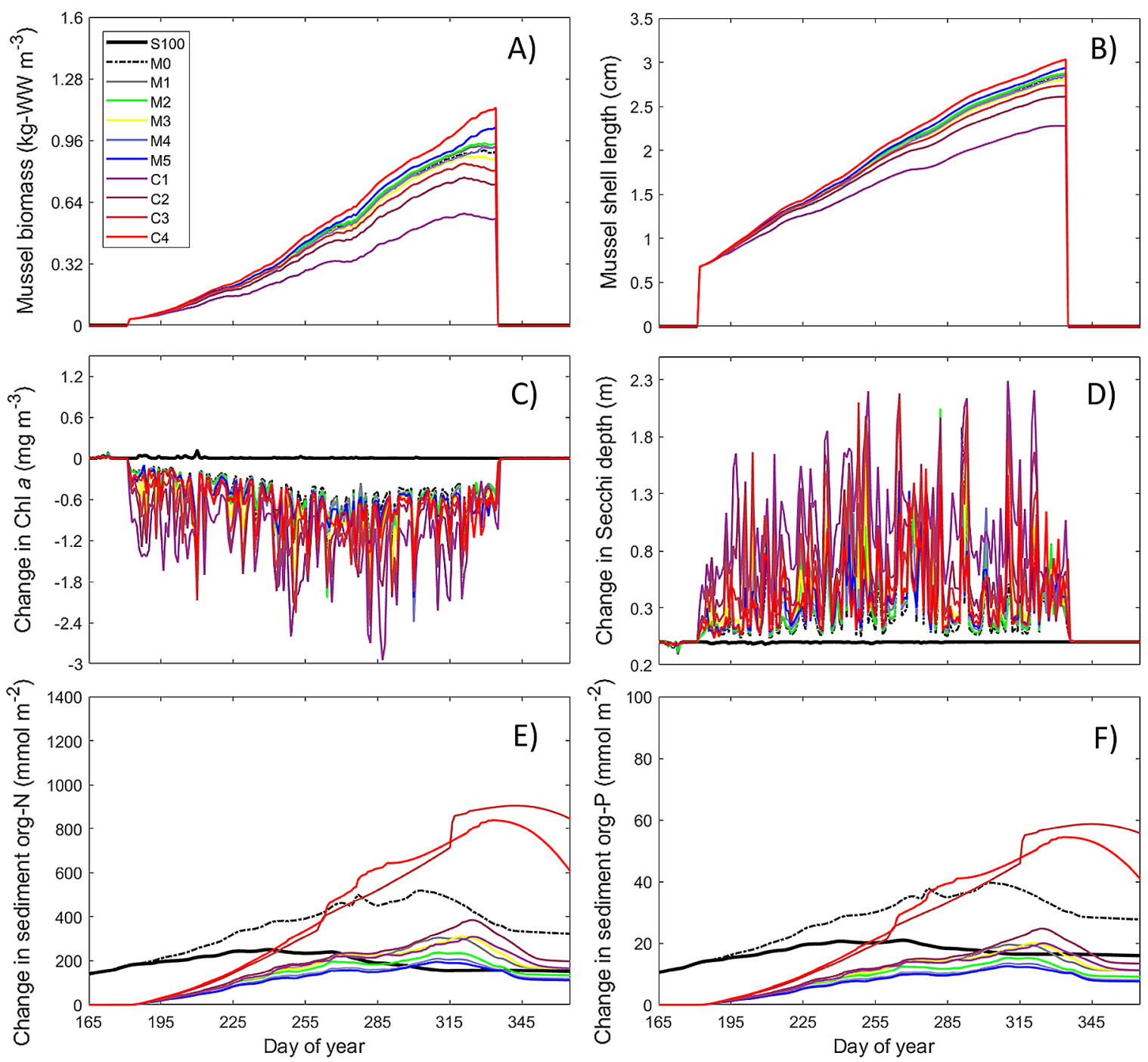

Fig. 5. (A) Biomass of mussels in the farms and (B) mussel shell length over time. Changes in (C) surface chl a concentrations, (D) Secchi depths, (E) sediment organic N content and (F) sediment organic P content relative to the reference scenario (REF) from June to December in the scenarios (S100, M0-M5, C1-C4). Mussel harvest is set to 1 December (Day 334)

ern and open water transects $\left(\mathrm{R}^{2}>0.85\right)$. The 4 coastal mussel farms (C1-C4) and the 2 open water farms closest to the coast (M3 and M5) resulted in less (negative) $\mathrm{N}$ transport relative to REF across Transect 2 (Table 4) and performed best among the farms (Table 3). For the eastern coastal areas (Transects 6-9), there was a reduction in $\mathrm{N}$ transport from $5.9 \mathrm{t} \mathrm{N}$ in $\mathrm{S} 100$ to $1.7-4.3 \mathrm{t} \mathrm{N}$ in scenarios with mussel farms (Fig. 6D). The transport to the Kattegat/North Sea was reduced from $8.5 \mathrm{t} \mathrm{N}$ in $\mathrm{S} 100$ to $2.3-5.3 \mathrm{t} \mathrm{N}$ in scenarios with mussel farms (Fig. 6E). The $\mathrm{N}$ transport to the Great Belt/Baltic Sea was the lowest, with $4.8 \mathrm{t} \mathrm{N}$ in S100 and correlated negatively with increasing $\mathrm{N}$ removal by mussel farms (Fig. 6F). P transport followed overall the same pattern as for $\mathrm{N}$ transport, except that the $\mathrm{P}$ reduction relative to $\mathrm{S} 100$ (average $=0.40$ ) was higher than the $\mathrm{N}$ reduction relative to $\mathrm{S} 100$ (average $=0.47)($ Table 4$)$. In many cases (Transects 1, 2, 6,7 and 10), even the $\mathrm{P}$ transport relative to REF became negative, indicating high $\mathrm{P}$ retention in the mussel farm area (Table 4).

\subsection{Environmental effects in the water column}

Chl a concentration within the mussel farm area decreased immediately after larvae settled in all scenarios, and the effect increased during July and August, whereupon it stabilized with high day-to- 
Table 2. Overview of mussel farm locations, means \pm SD of bottom velocity and surface environmental conditions (July to November), harvested mussel biomass and $\mathrm{N}$ and $\mathrm{P}$ removal by harvest on 1 December in the scenarios (farm size $=36$ ha). The last column shows the potential range (minimum/maximum difference from the mean) of harvested biomass and $\mathrm{N}$ and $\mathrm{P}$ removal. WW: wet weight

\begin{tabular}{|c|c|c|c|c|c|c|c|c|c|c|}
\hline Scenario & $\begin{array}{l}\text { Bottom } \\
\text { velocity } \\
\left(\mathrm{m} \mathrm{s}^{-1}\right)\end{array}$ & $\begin{array}{l}\text { Surface } \\
\text { salinity }\end{array}$ & $\begin{array}{c}\text { Surface } \\
\text { temperature } \\
\left({ }^{\circ} \mathrm{C}\right)\end{array}$ & $\begin{array}{c}\text { Surface } \\
\text { chl } a \\
\left(\mathrm{mg} \mathrm{m}^{-3}\right)\end{array}$ & $\begin{array}{c}\text { Surface } \\
\text { velocity } \\
\left(\mathrm{m} \mathrm{s}^{-1}\right)\end{array}$ & $\begin{array}{c}\text { Food } \\
\text { flux } \\
\left(\mathrm{mg} \mathrm{m}^{-2} \mathrm{~s}^{-1}\right)\end{array}$ & $\begin{array}{c}\text { Harvested } \\
\text { biomass } \\
\text { (t WW) }\end{array}$ & $\underset{\substack{\mathrm{N} \\
\text { removal }}}{\mathrm{t})}$ & $\begin{array}{c}\mathrm{P} \\
\text { removal } \\
\text { (t) }\end{array}$ & $\begin{array}{c}\text { Range } \\
(\%)\end{array}$ \\
\hline \multicolumn{11}{|c|}{ Open waters } \\
\hline M0 & $0.05 \pm 0.04$ & $20.2 \pm 3.0$ & $14.1 \pm 2.3$ & $1.86 \pm 0.67$ & $0.44 \pm 0.29$ & $0.87 \pm 0.77$ & 2184 & 27.1 & 2.46 & $-15 / 31$ \\
\hline M1 & $0.05 \pm 0.05$ & $19.7 \pm 2.8$ & $14.3 \pm 2.5$ & $1.81 \pm 0.69$ & $0.63 \pm 0.42$ & $1.21 \pm 1.11$ & 2194 & 27.1 & 2.47 & $-18 / 27$ \\
\hline M2 & $0.07 \pm 0.06$ & $21.4 \pm 3.0$ & $13.8 \pm 2.0$ & $1.84 \pm 0.67$ & $0.48 \pm 0.30$ & $0.93 \pm 0.82$ & 2298 & 27.5 & 2.51 & $-20 / 25$ \\
\hline M3 & $0.05 \pm 0.04$ & $21.2 \pm 2.9$ & $13.9 \pm 2.1$ & $1.90 \pm 0.66$ & $0.36 \pm 0.25$ & $0.72 \pm 0.66$ & 2110 & 26.3 & 2.38 & $-16 / 25$ \\
\hline M4 & $0.08 \pm 0.06$ & $21.6 \pm 3.3$ & $13.7 \pm 2.0$ & $1.89 \pm 0.66$ & $0.46 \pm 0.29$ & $0.91 \pm 0.77$ & 2194 & 27.1 & 2.47 & $-18 / 27$ \\
\hline M5 & $0.08 \pm 0.09$ & $20.7 \pm 3.0$ & $13.9 \pm 2.1$ & $1.97 \pm 0.64$ & $0.43 \pm 0.25$ & $0.88 \pm 0.67$ & 2370 & 28.8 & 2.67 & $-19 / 25$ \\
\hline \multicolumn{11}{|c|}{ Coastal waters } \\
\hline $\mathrm{C} 1$ & $0.05 \pm 0.03$ & $17.5 \pm 3.0$ & $14.9 \pm 3.2$ & $2.05 \pm 0.68$ & $0.09 \pm 0.05$ & $0.18 \pm 0.14$ & 1293 & 16.8 & 1.46 & $-9 / 11$ \\
\hline $\mathrm{C} 2$ & $0.05 \pm 0.03$ & $19.0 \pm 2.7$ & $14.5 \pm 2.7$ & $1.97 \pm 0.67$ & $0.20 \pm 0.14$ & $0.41 \pm 0.39$ & 1712 & 21.9 & 1.93 & $-11 / 17$ \\
\hline C3 & $0.01 \pm 0.01$ & $20.3 \pm 2.8$ & $14.2 \pm 2.3$ & $1.95 \pm 0.66$ & $0.28 \pm 0.21$ & $0.57 \pm 0.55$ & 1912 & 24.2 & 2.15 & $-13 / 23$ \\
\hline $\mathrm{C} 4$ & $0.02 \pm 0.02$ & $20.1 \pm 2.8$ & $14.1 \pm 2.3$ & $2.03 \pm 0.63$ & $0.40 \pm 0.22$ & $0.82 \pm 0.61$ & 2579 & 30.9 & 2.90 & $-19 / 24$ \\
\hline
\end{tabular}

day variability (Fig. 5C). On average, the reduction relative to REF was highest for the coastal stations C1-C3, with up to $1.22 \mathrm{mg} \mathrm{m}^{-3}$, and lowest for the open water stations, with $0.55-0.71 \mathrm{mg} \mathrm{m}^{-3}$ (Fig. 7A). Spatially, the decrease in chl a covered a larger area around the coastal farms (Fig. 8G-J) compared to the open water farms, where M3 showed the highest impact among the open water farms. Secchi depth showed an immediate increase after the introduction of mussel farms with high temporal variability (Fig. 5D). The average increase in Secchi depth was highest at C1 with $1.1 \mathrm{~m}$ and lowest at M0 with $0.3 \mathrm{~m}$ relative to REF (Fig. 7B). After harvesting the mussels, the effects on chl $a$ concentrations and Secchi depths in the water column were undetectable (Fig. 5C,D). In S100, there was no clear effect on either chl a concentrations and Secchi depths within the fish farm area relative to REF due to dilution by currents and grazing by zooplankton (Maar et al. 2018a). Hence, the coastal stations $\mathrm{C} 1-\mathrm{C} 3$ performed best in relation to $\mathrm{chl} a$ depletion and $\mathrm{C} 1$ and $\mathrm{C} 2$ for improvements of Secchi depth among the farms (Table 3). Primary production decreased in all scenarios with mussel farms and increased at S100 compared to REF and followed the same pattern as for chl a between scenarios (Fig. 7A,C). DIN and $\mathrm{PO}_{4}$ concentrations increased both in the fish farm area (S100) and the mussel farm areas compared to REF due to nutrient excretion from fish or mussels (Fig. 7D,E). At the co-located farm (M0), the change in surface DIN concentration was highest $\left(0.12 \mathrm{mmol} \mathrm{m}^{-3}\right)$ among the open water stations due to combined fish and mussel excretion. The coastal farms C1 and C2 showed similar high changes in DIN concentrations as $\mathrm{M} 0$ and hence a poor performance (Table 3). The highest changes in surface $\mathrm{PO}_{4}$ concentration $\left(0.09-0.15 \mathrm{mmol} \mathrm{m}{ }^{-3}\right)$ were found at C1-C3 (Fig. 7E). The surface $\mathrm{PO}_{4}$ concentration increased less at the fish farm compared to the mussel farms because $56 \%$ of the fish waste was solid and lost to the bottom. Bottom oxygen concentrations decreased below the farms, with the highest changes (up to $26 \mathrm{mmol} \mathrm{m}^{-3}$ ) at $\mathrm{M} 0, \mathrm{C} 3$ and C4 relative to REF (Fig. 7F).

\subsection{Benthic impact}

In July and August, the change in sediment organic $\mathrm{N}$ and $\mathrm{P}$ content compared to REF was highest at S100 and M0 due to the fish farm impact starting on 1 April, whereas the mussel farms started to operate on 1 July (Fig. 5E,F). The 2 coastal farms C3 and C4 showed the highest impact over time exceeding that of the fish farm (S100) and M0. Bottom current speed was lowest at C3 and C4, and these farms therefore had a lower resuspension rate and dispersal of sediment than the other farms (Table 2). All locations showed higher $\mathrm{N}$ and $\mathrm{P}$ sediment contents, ranging from 111 to $845 \mathrm{mmol} \mathrm{N}$ $\mathrm{m}^{-2}$ and from 8 to $56 \mathrm{mmol} \mathrm{P} \mathrm{m}{ }^{-2}$, compared to REF by the end of the year. The average change in sediment organic $\mathrm{N}$ was highest (300 $\mathrm{mmol} \mathrm{N} \mathrm{m}^{-2}$ ) at $\mathrm{C} 3$ and $\mathrm{C} 4$ with low resuspension and at $\mathrm{M} 0$ due to the combined sedimentation of both solid fish waste 

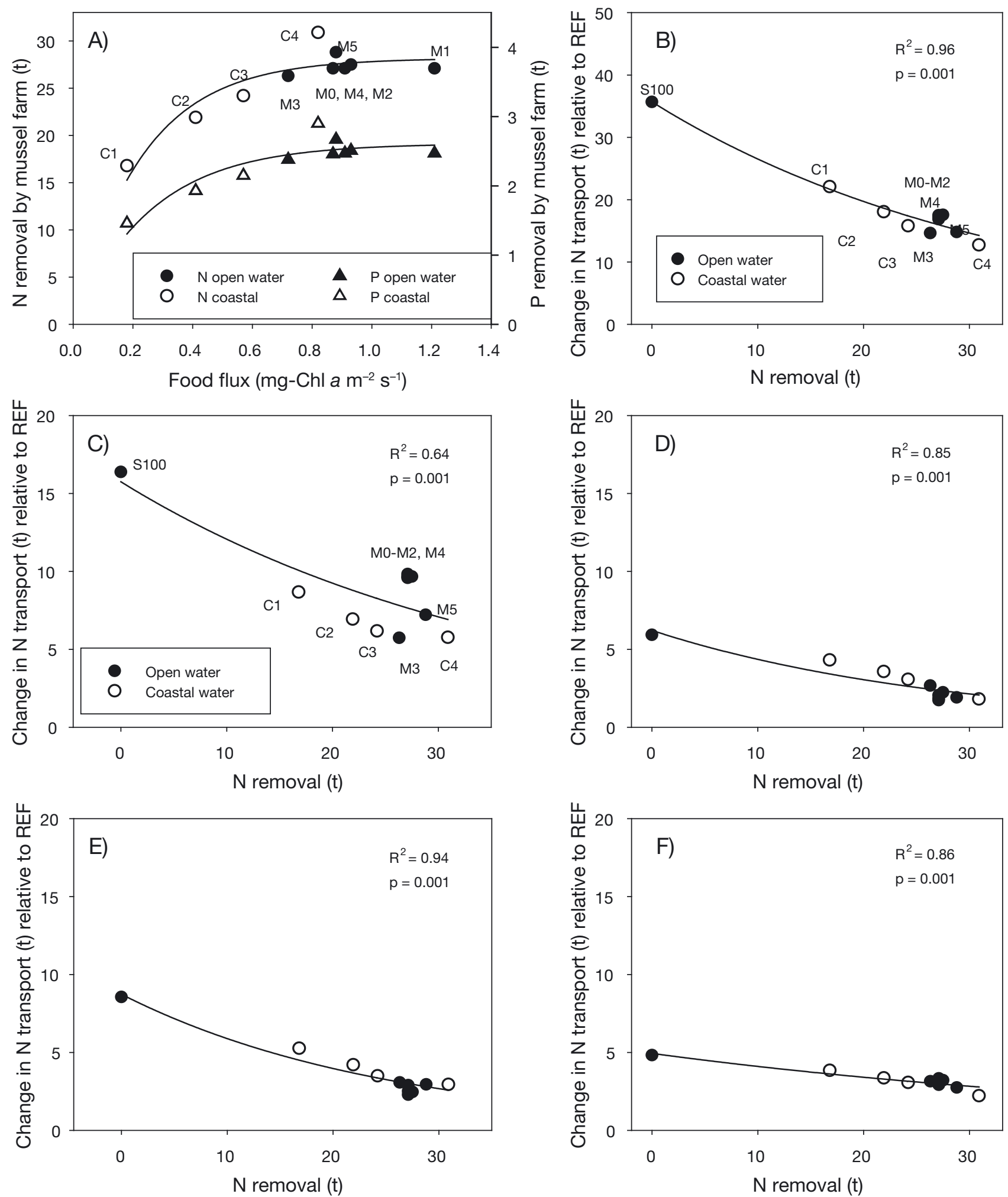

Fig. 6. (A) Total $\mathrm{N}$ and $\mathrm{P}$ removal per mussel farm by harvest as a function of food flux. (B-F) Change in gross $\mathrm{N}$ transport across different transects (see Fig. 2) relative to the reference scenario (REF): (B) all transects (1-11), (C) western coastal areas (Transects 1-5), (D) eastern coastal areas (Transects 6-9), (E) the Kattegat (Transect 10) and (F) the Great Belt (Transect 11) when adding a mussel farm into coastal areas (C1-C4) or open waters (M0-M5) to compensate for the fish farm nutrient inputs (S100). Scenario names are only indicated in panels A-C, but D-F follow the same pattern as B 
Table 3. Ranking of scenarios (farm location) based on changes in water quality and sediment impacts. Positive effects: $\mathrm{N}$ removal by harvesting, reduced transport to the western EU Water Framework Directive (WFD) area, reduced chl a concentration, higher Secchi depth and higher denitrification. Negative effects: higher surface dissolved inorganic nitrogen (DIN) concentrations, higher sediment organic $\mathrm{N}$ content, higher $\mathrm{NH}_{4}$ flux from sediment and higher sediment oxygen consumption. 'Green' = best performance (ratio $>0.66$ ), 'orange' $=$ medium performance (ratio $=0.33-0.66)$ and 'red' $=$ poor performance $($ ratio $<0.33$ )

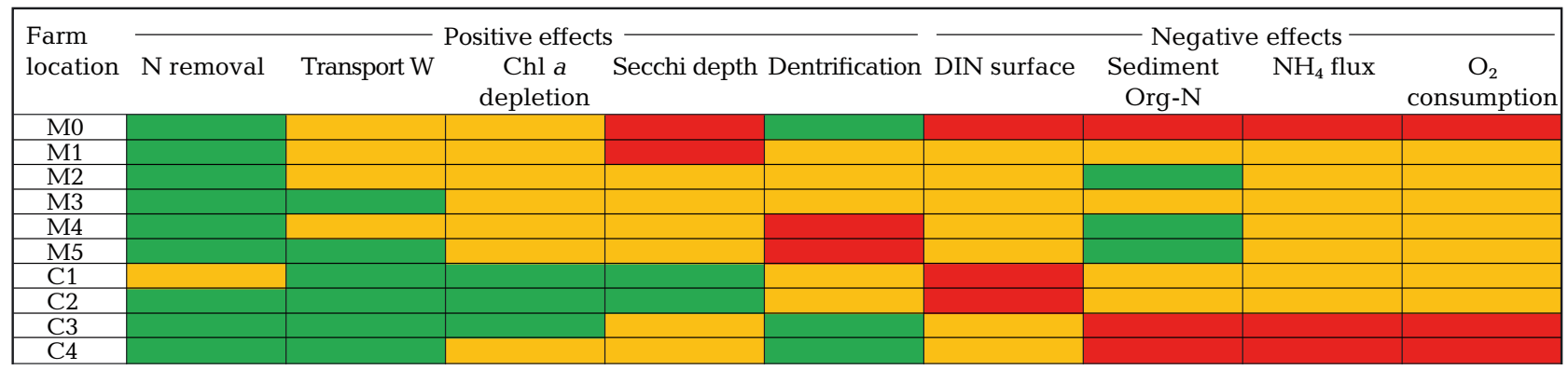

Table 4. Difference in gross transport of total N ( $\mathrm{t}$ ) and total P (t) across different transects (see Fig. 2B) between scenarios (fish and mussel farms) and the reference scenario (REF). W (E): western (eastern) coastal area transect; NS: North Sea transect; BS: Baltic Sea transect. The last column shows the average change in N or P transport in scenarios with both mussel and fish farms (not S100) for each transect compared to REF

\begin{tabular}{|c|c|c|c|c|c|c|c|c|c|c|c|c|c|c|}
\hline \multirow[t]{2}{*}{ No. } & \multirow[t]{2}{*}{ Transect } & \multirow{2}{*}{$\begin{array}{l}\text { Transect } \\
\text { area }\end{array}$} & \multirow[b]{2}{*}{ S100 } & \multicolumn{4}{|c|}{ Farms in open waters } & \multirow{2}{*}{$\mathrm{M} 4$} & \multirow[b]{2}{*}{ M5 } & \multicolumn{4}{|c|}{ - Farms in coastal waters - } & \multirow{2}{*}{$\begin{array}{c}\text { Change } \\
\text { in transports }\end{array}$} \\
\hline & & & & M0 & M1 & M2 & M3 & & & $\mathrm{C} 1$ & $\mathrm{C} 2$ & C3 & $\mathrm{C} 4$ & \\
\hline \multicolumn{15}{|c|}{ Nitrogen } \\
\hline 1 & Samsø Belt N & $\mathrm{W}$ & 6.0 & 1.9 & 1.5 & 1.1 & 2.0 & 2.5 & 2.4 & 3.6 & 2.8 & 2.4 & 2.3 & 2.3 \\
\hline 2 & Samsø Belt NW & $\mathrm{W}$ & 2.6 & 1.3 & 2.2 & 2.4 & -2.1 & 1.2 & -0.3 & -1.6 & -2.4 & -2.6 & -2.0 & -0.4 \\
\hline 3 & Samsø Belt SW & $\mathrm{W}$ & 5.6 & 5.0 & 4.7 & 4.7 & 4.4 & 4.7 & 4.1 & 4.9 & 4.9 & 5.0 & 4.4 & 4.7 \\
\hline 4 & Romsø Sund & $\mathrm{W}$ & 1.7 & 1.1 & 1.2 & 1.2 & 1.1 & 1.0 & 0.9 & 1.4 & 1.2 & 1.1 & 0.8 & 1.1 \\
\hline 5 & Kerteminde Bugt & $\mathrm{W}$ & 0.5 & 0.3 & 0.3 & 0.3 & 0.3 & 0.2 & 0.2 & 0.4 & 0.3 & 0.3 & 0.2 & 0.3 \\
\hline 6 & Sejrøbugten N & $\mathrm{E}$ & 1.2 & 0.3 & 0.2 & 0.3 & 0.5 & 0.3 & 0.4 & 0.8 & 0.7 & 0.6 & 0.4 & 0.5 \\
\hline 7 & Sejrøbugten S & E & 1.6 & 0.1 & 0.2 & 0.3 & 0.5 & 0.1 & 0.2 & 1.1 & 0.8 & 0.7 & 0.2 & 0.4 \\
\hline 8 & Kalundborg Fjord & d E & 1.4 & 0.5 & 0.6 & 0.6 & 0.7 & 0.4 & 0.4 & 1.1 & 0.9 & 0.8 & 0.4 & 0.6 \\
\hline 9 & Musholm Bugt & E & 1.7 & 0.9 & 1.1 & 1.0 & 1.0 & 0.9 & 0.8 & 1.4 & 1.2 & 1.0 & 0.8 & 1.0 \\
\hline 10 & Kattegat & NS & 8.5 & 2.5 & 2.3 & 2.5 & 3.1 & 2.9 & 2.9 & 5.3 & 4.2 & 3.5 & 2.9 & 3.2 \\
\hline \multirow[t]{2}{*}{11} & Great Belt & BS & 4.8 & 2.9 & 3.3 & 3.2 & 3.1 & 2.9 & 2.7 & 3.8 & 3.4 & 3.1 & 2.2 & 3.1 \\
\hline & Total for $\mathrm{N}$ & & 35.7 & 16.8 & 17.5 & 17.6 & 14.6 & 17.2 & 14.8 & 22.1 & 18.1 & 15.8 & 12.7 & \\
\hline \multicolumn{15}{|c|}{ Phosphorus } \\
\hline 1 & Samsø Belt N & $\mathrm{W}$ & 0.50 & 0.02 & -0.03 & -0.07 & -0.04 & 0.09 & 0.08 & 0.23 & 0.14 & 0.08 & 0.07 & 0.06 \\
\hline 2 & Samsø Belt NW & $\mathrm{W}$ & 0.26 & 0.12 & 0.22 & 0.25 & -0.29 & 0.10 & -0.08 & -0.21 & -0.34 & -0.34 & -0.23 & -0.08 \\
\hline 3 & Samsø Belt SW & $\mathrm{W}$ & 0.73 & 0.71 & 0.64 & 0.66 & 0.64 & 0.66 & 0.61 & 0.66 & 0.67 & 0.70 & 0.66 & 0.66 \\
\hline 4 & Romsø Sund & $\mathrm{W}$ & 0.16 & 0.10 & 0.11 & 0.11 & 0.10 & 0.09 & 0.07 & 0.13 & 0.11 & 0.09 & 0.07 & 0.10 \\
\hline 5 & Kerteminde Bugt & $\mathrm{W}$ & 0.04 & 0.01 & 0.02 & 0.02 & 0.01 & 0.01 & 0.00 & 0.03 & 0.02 & 0.01 & 0.00 & 0.01 \\
\hline 6 & Sejrøbugten N & $\mathrm{E}$ & 0.09 & -0.02 & -0.03 & -0.01 & 0.01 & -0.01 & 0.00 & 0.05 & 0.03 & 0.02 & 0.01 & 0.01 \\
\hline 7 & Sejrøbugten S & $\mathrm{E}$ & 0.11 & -0.05 & -0.04 & -0.03 & 0.00 & -0.05 & -0.04 & 0.06 & 0.04 & 0.02 & -0.03 & -0.01 \\
\hline 8 & Kalundborg Fjord & d E & 0.11 & 0.01 & 0.02 & 0.03 & 0.03 & 0.00 & 0.00 & 0.08 & 0.06 & 0.04 & 0.00 & 0.03 \\
\hline 9 & Musholm Bugt & $\mathrm{E}$ & 0.17 & 0.08 & 0.10 & 0.10 & 0.10 & 0.08 & 0.08 & 0.14 & 0.11 & 0.10 & 0.07 & 0.10 \\
\hline 10 & Kattegat & NS & 0.70 & 0.02 & -0.01 & 0.01 & 0.09 & 0.06 & 0.07 & 0.34 & 0.22 & 0.14 & 0.08 & 0.10 \\
\hline \multirow[t]{2}{*}{11} & Great Belt & $\mathrm{BS}$ & 0.55 & 0.37 & 0.41 & 0.40 & 0.39 & 0.36 & 0.34 & 0.45 & 0.40 & 0.38 & 0.31 & 0.38 \\
\hline & Total for P & & 3.41 & 1.38 & 1.43 & 1.46 & 1.13 & 1.39 & 1.14 & 1.95 & 1.49 & 1.24 & 1.01 & \\
\hline
\end{tabular}

and mussel pellets (Fig. 9A, Table 3). Change in sediment oxygen consumption was again highest at M0 (66 mmol m $\left.\mathrm{m}^{-2} \mathrm{~d}^{-1}\right)$, but showed a similar increase at C3 and C4 (Fig. 9B, Table 3). Denitrification increased at all locations relative to REF, with the highest changes $\left(0.28-0.30 \mathrm{mmol} \mathrm{N} \mathrm{m}^{-2} \mathrm{~d}^{-1}\right)$ at
M0, C3 and C4 (Fig. 9C, Table 3). Nutrient fluxes from the sediment increased at all locations relative to REF and showed a similar pattern for $\mathrm{PO}_{4}, \mathrm{NH}_{4}$ and $\mathrm{NO}_{3}$, with highest fluxes at $\mathrm{MO}, \mathrm{C} 3$ and $\mathrm{C} 4$ (Fig. 9D-F). Hence, the negative benthic impacts were highest at M0, C3 and C4 among the farms, 

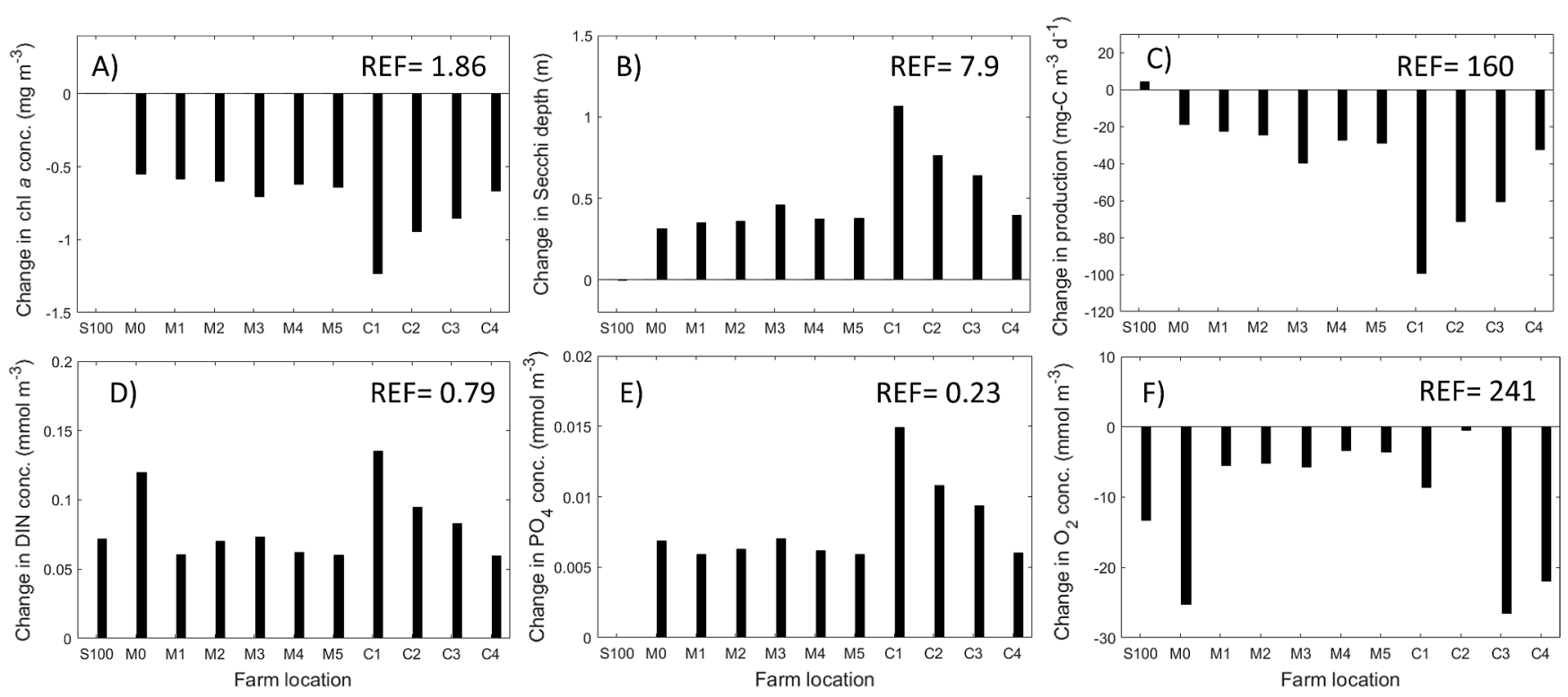

Fig. 7. Pelagic impact within the mussel farm area. Changes in (A) chl a concentration, (B) Secchi depth, (C) mesozooplankton production, (D) surface dissolved inorganic nitrogen (DIN) concentrations, (E) surface $\mathrm{PO}_{4}$ concentrations and (F) bottom $\mathrm{O}_{2}$ concentrations in the different scenarios relative to the reference scenario (REF) from July to November. The mean values for REF at the fish farm location are shown in the upper right corner

but these farms showed at the same time the highest positive effect on denitrification (Table 3).

\section{DISCUSSION}

The identification of suitable locations for mussel mitigation cultures in relation to fish farming requires the consideration of the mussels' nutrient removal efficiency and nutrient transports (far-field effects), as well as positive and negative environmental effects on the water column and on sediment conditions beneath the farm. The optimal mussel farm location was tested in a 3D ecological model by inserting 10 mussel farms either along the nearest affected coastline (C1-C4) or in open waters (M0-M5) in different directions and distances from the fish farm (Table 1, Fig. 4C).

\subsection{Nutrient removal efficiency}

The harvested mussel biomass in the model corresponded to $0.5-0.9 \mathrm{t} \mathrm{N} \mathrm{ha}^{-1}$ and $0.04-0.08 \mathrm{t} \mathrm{P} \mathrm{ha}^{-1}$ for a $6 \mathrm{~m}$ deep farm (Table 2). This was slightly higher than reported values for an operating long-line farm in the shallow Limfjorden with similar mussel densities (December harvest: $0.6 \mathrm{t} \mathrm{N} \mathrm{ha}^{-1}$ and $0.03 \mathrm{t} \mathrm{P}$ $\mathrm{ha}^{-1}$ ) due to the lower farm depth of 2-3 m (Petersen et al. 2014). The nutrient removal efficiency by the mussel farms in the model increased with increasing food flux and showed saturation $>0.7 \mathrm{mg} \mathrm{chl} a \mathrm{~m}^{-2}$ $\mathrm{s}^{-1}$, although with some natural variability between the farms (Fig. 6A). The 2 southernmost farms (C4 and M5), for example, showed slightly higher nutrient removal than the other stations, although the food flux was not among the highest (Table 2). This pattern suggests that a higher chl a level with lower current velocity stimulated mussel growth more than a lower chl a level with higher current velocity. In addition, mussel growth was temporally reduced in the model at low salinity $(<16.2)$ due to inflows from the Baltic Sea (Farm M1) or input from freshwater sources (Farms C1 and C2). At 3 of the coastal farms (C1-C3), the combination of lower salinity and lower food flux explained the lower nutrient removal. In the Baltic Sea, salinity is an important determinant of blue mussel size, which decreases towards the east and results in dwarfed mussels (Riisgård et al. 2012, Maar et al. 2015, Buer et al. 2020). In the Samsø Belt and western part of the Baltic Sea, the main species is Mytilus edulis, whereas $M$. trossolus and hybrids dominate to the east (Zbawicka et al. 2014). In comparison with nutrient loads from the fish farm (100 t $\mathrm{N}), 17-31 \%$ of the released $\mathrm{N}$ could be mitigated by 1 mussel farm (Table 2) and all farms, except C1, performed equally well according to the ranking of nutrient removal (Table 3). 

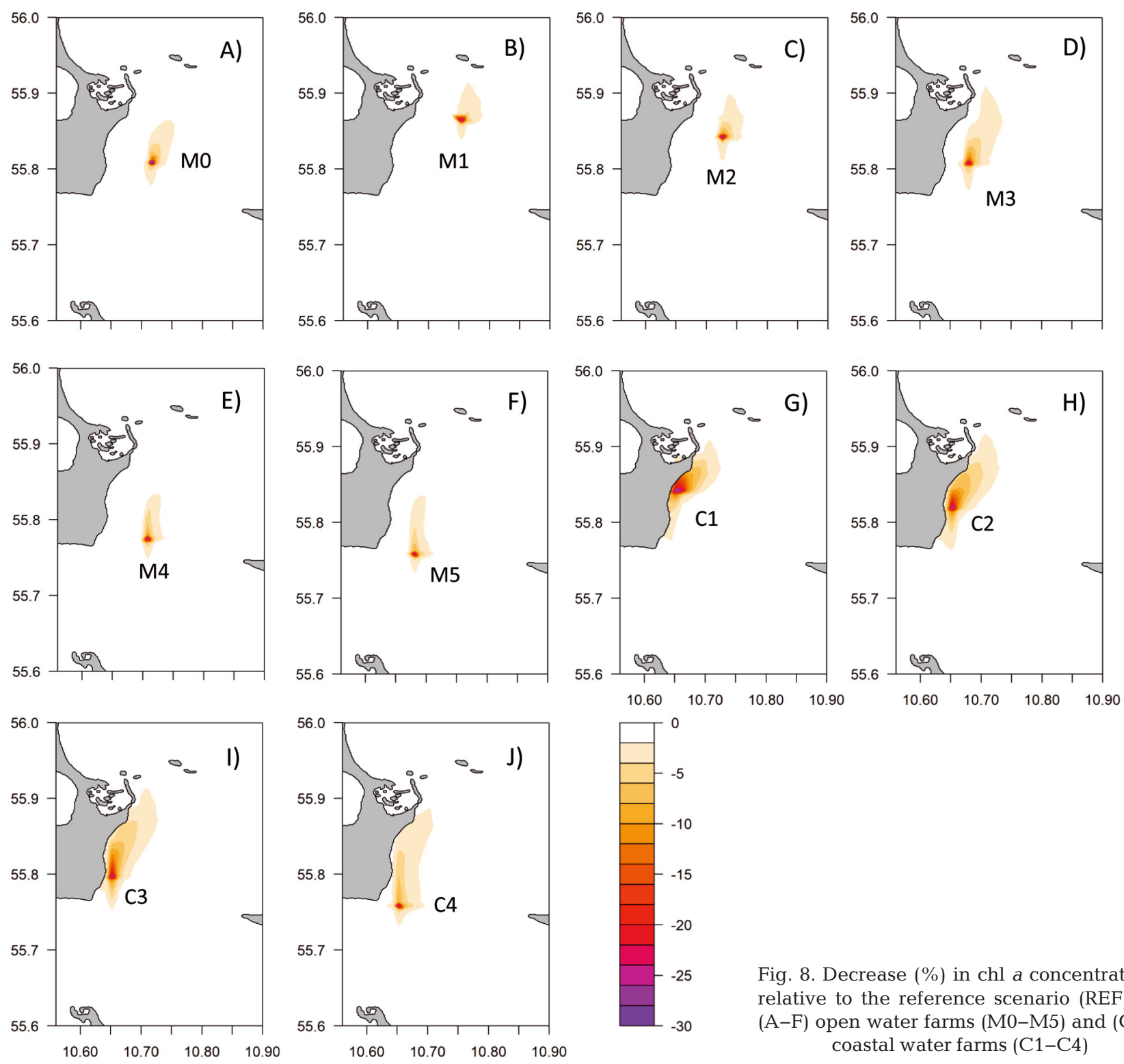

Fig. 8. Decrease (\%) in chl a concentrations relative to the reference scenario (REF) for $(\mathrm{A}-\mathrm{F})$ open water farms (M0-M5) and (G-J) coastal water farms $(\mathrm{C} 1-\mathrm{C} 4)$

\subsection{Nutrient transports}

The nutrient removal efficiency determines the amount of nutrient removal by mussel harvesting on site. However, it is equally important to consider the contribution of mussels to far-field effects by reducing nutrient transport to other potentially sensitive areas, such as coastal areas protected by the WFD or habitats protected at Natura 2000 sites. At all locations, the mussel farms reduced nutrient transport with increasing nutrient removal efficiency compared to the S100 scenario (with only the fish farm) (Fig. 6B). Nutrient transport from the fish farm was highest to the western coastal WFD area with a total

of $16.4 \mathrm{t} \mathrm{N}$ (Fig. 6C). However, a mussel farm could reduce the nutrient transport to this area by more than half compared to S100. The eastern coastal WFD area (Transects 6-9) also benefitted from the mussel farms compared to S100 (Fig. 6D), but was generally less affected by the fish farm $(5.9 \mathrm{t} \mathrm{N})$, probably due to the greater distance from the fish farm.

Considering the western WFD area (Transects 1-3), not only the nutrient removal efficiency, but also the farm location was important (Fig. 6C). Hence, the farms located within or closest to the western WFD areas (C1-C4, M3 and M5) resulted in less transport than for the farms located farther away (M0-M2, M4), which was also reflected in the ranking of the 

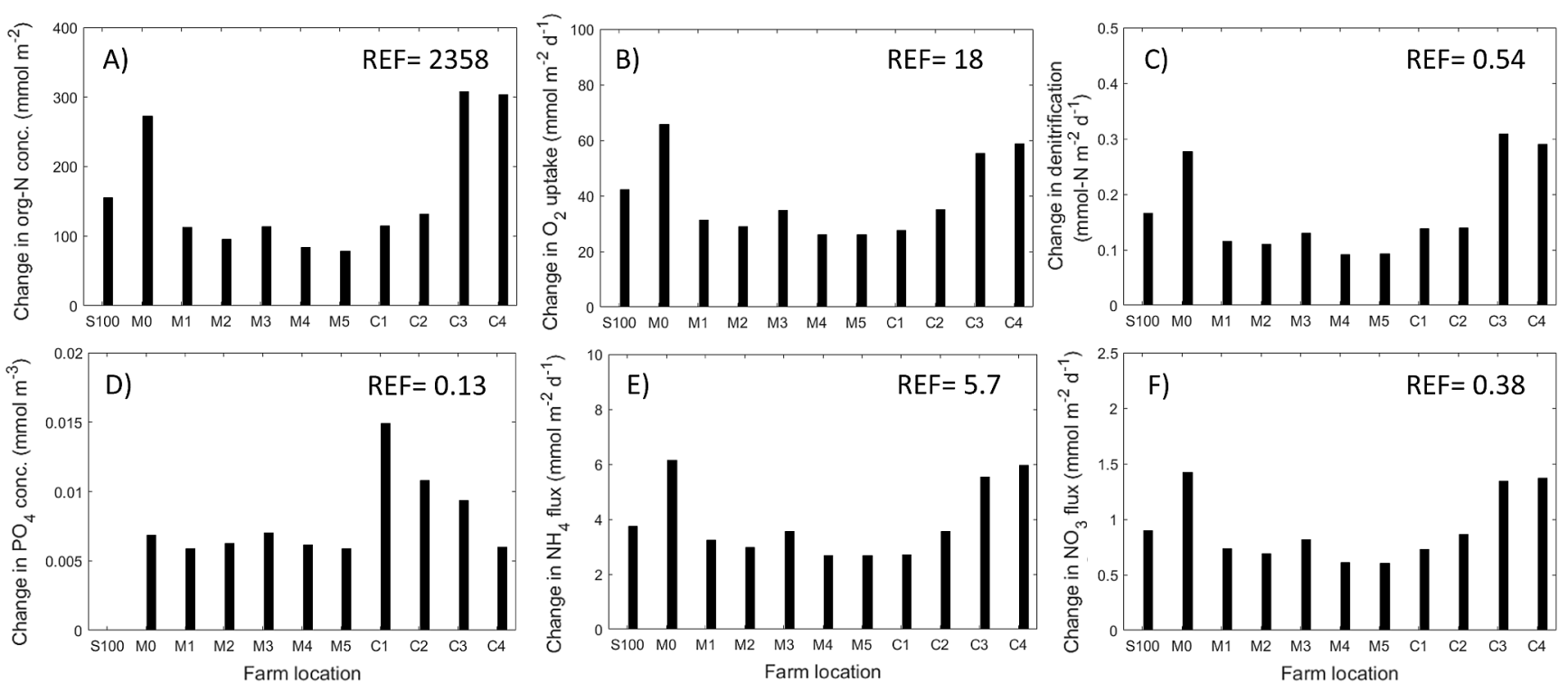

Fig. 9. Benthic impact below the farms. Changes in (A) sediment organic $N$ content, (B) $\mathrm{O}_{2}$ uptake by the sediment, (C) denitrification, (D) $\mathrm{PO}_{4}$ flux out of the sediment, $(\mathrm{E}) \mathrm{NH}_{4}$ flux out of the sediment and (F) $\mathrm{NO}_{3}$ flux out of the sediment in the different scenarios relative to the reference scenario (REF) from April to December. The mean values for REF at the fish farm location are shown in the upper right corner

farms (Table 3). Especially the transports across Transects 1 and 2 were reduced by the mussel farms (Table 4) due to their location in the main current direction from the farms. Despite the proximity of many of the mussel farms to Transect 3, they were not able to reduce nutrient transport efficiently towards this area (Table 4). The western coastal area, subject to the WFD, has a poor ecological status with high chl a concentrations and summer hypoxia (Maar et al. 2016, HELCOM 2018). Hence, the transport of nutrient loads from offshore fish farms to these coastal water areas, and their impact, is of concern. A fraction of the waste from the fish farm was transported with bottom water in the dominant southwestern current direction across Transect 3 according to the hydrodynamic model (Maar et al. 2018a). As the long-line mussel farms are restricted to the upper water column (ca. 0-8 m) with current techniques, mussels can only remove nutrients efficiently in the surface waters.

In other types of sensitive areas where nutrients may get trapped, such as sheltered bays and inlets, some of which are even protected as Natura 2000 areas, the contribution of mussel farms to reducing nutrient transport can be particularly valuable. Sheltered areas are close to Transects 2, 5 and 8 (Fig. 2B). There was only little nutrient transport $(<0.6 \mathrm{t} \mathrm{N}$ on average) across Transects 5 and 8 with mussel farms, and for Transect 2, there was even a net reduction (negative values) relative to REF (Table 4). Hence, most of the mussel farms were very efficient and caused fewer nutrients to be transported to these sheltered areas compared to S100. Several Natura 2000 sites are located within the study area and are all appointed due to the presence of reef habitats. The macroalgae forests at these sites are sensitive to nutrient concentrations affecting the light conditions (Krause-Jensen et al. 2007). Both coastal and open water mussel farms contributed to a reduction in nutrient concentrations in these areas. The nearest Natura 2000 site north of the fish farm could benefit the most from the mussel farms due to the high net reduction in nutrient transport, but also due to the decrease in chl a concentration (Fig. 8D,G-I).

The fish farm was located in open waters managed according to the EU Marine Strategy Framework Directive (MSFD). As part of the HELCOM area, it is also included in the Baltic Sea Action Plan (BSAP), which sets maximum allowable nutrient inputs to the different sub-basins (HELCOM 2007). Nutrients from the fish farm were transported to the neighboring MSFD waters through Transects 10 (Kattegat/North Sea) and 11 (Great Belt/Baltic Sea). Nutrient transport towards these transects was quite high (Table 4), although the mussel farms reduced $\mathrm{N}$ transport by 38\% (Transect 10) and 65\% (Transect 11), compared to S100. In addition, nutrients transported over those transects were dispersed into open waters, where they may have less impact than the more eutrophic coastal sites. However, the Baltic Proper is also in poor ecological condition, and further nutrient 
inputs can increase pelagic production contributing to bottom-up cascading effects on the pelagic food web (Bonsdorff et al. 1997).

\subsection{Environmental impacts on the water column}

Mussels filter the water for phytoplankton, while at the same time excreting nutrients and producing feces that sink to the bottom (Petersen et al. 2019a). The environmental impacts can therefore be both positive and negative. Mussel filtration caused a clear, positive effect by reducing chl a concentration and increasing Secchi depths at all farm locations (Fig. 7A,B). The coastal farms C1-C3 showed the highest improvements in chl a (Table 3), although the nutrient removal efficiency was lower. This was due to the lower current speeds (Table 2) and hence less renewal by advection (Petersen et al. 2019b). The open water farms (M0-M5) only decreased chl $a$ in the open waters, whereas the coastal farms contributed to a decrease in the coastal waters and hence the WFD areas (Fig. 8), which need an improvement of water quality. The estimated reduction in chl a concentration and increase in Secchi depths were similar to previously reported values from field studies (Petersen et al. 2008, 2019b, Cranford et al. 2014, Nielsen et al. 2016) and modeling studies (Grant et al. 2008, Schröder et al. 2014, Timmermann et al. 2019).

Farms C1 and C2, with the highest improvements of Secchi depth, were, at the same time, the ones with the highest increase in surface DIN and $\mathrm{PO}_{4}$ concentrations (Table 3) due to the lower current dilution and less uptake by lower phytoplankton biomass (Figs. 7D,E). A fraction of the ingested nutrients bound in phytoplankton biomass is excreted again as dissolved nutrients by the mussels. In addition, a fraction of the nutrients in mussel feces was recycled over time, increasing sediment nutrient fluxes to the bottom water (Fig. 9D-F). The nutrient release from the mussel farm can result in negative effects through an increase in primary production, but this was not found here due to the depletion of phytoplankton biomass. In any case, there will always be a net removal of nutrients into mussel biomass, despite the transformation between nutrient fractions by mussel activities (Holmer et al. 2015, Petersen et al. 2019a).

\subsection{Benthic impacts}

The coastal farms C3 and C4 and the co-located farm M0 showed the highest negative impact in terms of sediment accumulation of organic $\mathrm{N}$ and $\mathrm{P}$ content and oxygen consumption (Figs. 5E,F \& $9 \mathrm{~A}, \mathrm{~B})$. The negative impact of the co-location scenario was expected due to the combined increase in bio-deposition from the fish and mussel farms. The 2 coastal farms featured relatively high mussel biomass combined with a low average bottom velocity of 0.01 to $0.02 \mathrm{~m} \mathrm{~s}^{-1}$ causing less resuspension than at the other sites (Table 2). A bottom velocity of $>0.02 \mathrm{~m} \mathrm{~s}^{-1}$ has been identified as the threshold for the accumulation of feces in sediments below a fish farm (Valdemarsen et al. 2015) and can be used to exclude potential mussel farm locations to avoid strong benthic impacts (von Thenen et al. 2020). At the other sites, benthic impact was low due to resuspension and dilution by currents, and the increased sediment oxygen consumption affected the bottom water $\mathrm{O}_{2}$ concentration by $<5 \%$ (Fig. 7F). The different sediment fluxes $\left(\mathrm{O}_{2}\right.$ uptake, denitrification and phosphate, ammonium and nitrate release) showed overall similar responses between farm locations (Fig. 9B-F), because the biodeposition from fish and mussel farms was much higher than the background sedimentation, and the difference between sites depended on the amount of resuspension.

Organic enrichment of the sediment, e.g. below fish and mussel farms, can increase denitrification and hence have a positive effect on the nitrogen removal from the system (Carlsson et al. 2012). The model estimated that denitrification would increase on average $17-57 \%$ below the farms compared to the reference scenario (Fig. 9C), which is similar to previous studies of bivalve farming (Carlsson et al. 2009, Petersen et al. 2019a). On the other hand, increased respiration of organic matter in the sediment can lead to anoxia and inhibition of the coupled nitrification-denitrification process (Holmer et al. 2015). Likewise, phosphate bound to metals in the sediment will be released to the water column during anoxic conditions (Holmer et al. 2003). In this case, nutrient fluxes to the bottom water will increase, and the net removal of nutrients from the system will be less than expected (Nizzoli et al. 2011). In the present study, C3, C4 and M0 showed the highest accumulation of organic matter and hence the highest risk for developing anoxia and inhibition of denitrification over time (Fig. 5E,F). The ranking of farms showed that the same 3 farms (C3, C4 and M0) either showed the best performance in relation to denitrification or the worst performance in relation to the negative benthic effects (Table 3). 


\subsection{Site selection}

All farm locations showed trade-offs with respect to the considered effects, and no farm performed the best at all times (Table 3). Taking into account the number of positive effects, the coastal farm $\mathrm{C} 2$ performed slightly better, closely followed by the nearby coastal farms $\mathrm{C} 1$ and $\mathrm{C} 3$. However, both $\mathrm{C} 3$ and $\mathrm{C} 4$ generated high benthic impacts due to low bottom currents and were not considered suitable for mitigation purposes. The same applies to the co-location of mussel and fish farms, which also showed high benthic impacts and low positive effects on Secchi depth. When considering organic enrichment, the open water farms M2, M4 and M5 performed best due to higher resuspension. The 2 open water farms closest to the western coastal area (M3 and M5) performed well with respect to nutrient removal and transports and with medium impacts for the other effects (Table 4). Hence, a good location of open water mussel farms could be a few $\mathrm{km}$ outside the affected sensitive area acting as a nutrient filter. With respect to the considered effects, the model results showed that mussel mitigation cultures could be placed both in coastal areas as well as in open waters outside the fish farm. The model exercise only tested 10 potential sites for mussel mitigation cultures to identify the most important criteria for the site selection, but other more optimal sites may exist in their vicinity, e.g. where both bottom currents $\left(>0.02 \mathrm{~m} \mathrm{~s}^{-1}\right)$ and surface food fluxes are optimal for the mitigation effects (Holbach et al. 2020). However, it is up to the managers to decide which positive and negative effect should receive the most attention given the present need for protection of water bodies and habitats.

\subsection{Marine spatial planning}

In addition to environmental effects and mitigation potential, site selection should also include other uses at sea. In the EU, all countries with marine areas have to establish maritime spatial plans to coordinate marine uses and avoid conflicts (Directive 2014/89/EU). Potential development areas for aquaculture can be designated in these plans (Veidemane et al. 2017), which provides more security for developers and companies. Integrating site selection of fish and mussel farms into marine spatial planning furthermore supports the identification of optimal locations, where environmental impacts and conflicts with other marine uses are acceptable (Sanchez-Jerez et al. 2016, Lester et al. 2018).

Marine and coastal uses in the Samsø Belt that could potentially conflict with aquaculture include Natura
2000 sites, recreational and leisure activities, and shipping. The conservation status for the reefs in the Natura 2000 sites in this area is unfavorable, according to the latest assessment (EIONET 2019). None of the mussel farms are located in a Natura 2000 site, and the mussels can efficiently reduce nutrient transport to the designated sites in close proximity as mentioned earlier. From this point of view, the mussel farms would not negatively impact any sites. However, nutrient transport from the fish farm to the coastal and open marine areas may infringe the thresholds set by the WFD and BSAP, respectively, and further contribute to a deterioration of the conservation status in the Natura 2000 sites. Nevertheless, using mussel farms as a mitigation measure for fish farms does decrease nutrient transport overall; all scenarios with mussel farms performed better than S100. To communicate this to different stakeholders can be an important contribution of stakeholder engagement activities, to increase knowledge and reduce conflicts (Mazur \& Curtis 2008). In the public perception, the negative impacts of mussel farms may outweigh their benefits. In Denmark, this is partly due to a negative perception of aquaculture in general, caused by environmental concerns around fish farms that are projected onto mussel farms (Petersen \& Stybel 2019). The open water farms have less adverse environmental impacts and they are located further offshore. This reduces conflicts with nearshore recreational activities as well as the visual impact, which is another factor that can be considered in spatial planning (Longdill et al. 2008, Lester et al. 2018). The coastal farms, however, are more efficient at decreasing chl $a_{\text {, which }}$ could be beneficial for benthic vegetation due to the increase in water transparency. With respect to commercial shipping, marine spatial planning can identify major shipping routes in the area, such as International Maritime Organization deepwater shipping routes, and ensure that no conflicts arise with the location of the fish and mussel farms. The same applies to passenger and leisure vessels crossing the area.

\subsection{Model uncertainties}

Validation of the ecological model showed a good performance using data from 3 monitoring stations in a previous study, which also discussed the uncertainties related to the environmental impact from the fish farm (Maar et al. 2018a). In the present study, the ecological model was coupled to the DEB model to describe individual mussel growth in response to temperature, salinity and food concentrations. The 
DEB model has previously been applied and validated for Danish ecosystems (Maar et al. 2015, 2018b), and we therefore believe that the simulated differences in seasonal and spatial growth patterns between the farms were realistic. The highest uncertainty of the DEB model estimates is often related to the $X_{\mathrm{k}}$ value, because it varies according to the given food conditions and food quality (Bacher \& Gangnery 2006). The uncertainty test with different $X_{\mathrm{k}}$ values showed that the modeled mean values of mussel harvest and nutrient removal potentially could vary by -20 to $+31 \%$ within a mussel farm. This estimate is comparable to field data, where the standard deviation for mussel farm $\mathrm{N}$ removal was $\pm 20-33 \%$ of the mean value between all sites and seasons (Taylor et al. 2019). The farm biomass was estimated from the individual mussel biomass multiplied by the population density per $\mathrm{m}^{3}$ of the farm based on a previous study in the Limfjorden (Nielsen et al. 2016). A more recent study in the Limfjorden showed that mussel abundance in the farm could be increased by a factor of 2 in order to achieve a higher harvest (Taylor et al. 2019). Hence, the nutrient removal estimated by the farms in the present study is a conservative estimate, as the density of mussels potentially could be increased by increasing the number of loops, extending the loops further with depth or using another farm system, e.g. nets (Taylor et al. 2019). Suspended mussel cultures were not feeding on fish pellets in the model although they may be able to do so on the smaller fish waste fractions (Cranford et al. 2013, Irisarri et al. 2013, Lander et al. 2013). However, only a small fraction of the solid fish waste is available for mussel filtration, and previous model studies showed that mussels were not able to reduce the biodeposition significantly below IMTAs (Cranford et al. 2013, Filgueira et al. 2017). Further, field studies revealed that feed waste only constituted a small part of the mussel diet in IMTAs (Irisarri et al. 2015, Sanz-Lazaro \& Sanchez-Jerez 2017). If mussels were allowed to ingest some of the smaller fish waste fractions in the co-location scenario, the reduction in the benthic impact would probably still be limited due to a low retention time of particles within the fish farm and due to a low food preference for fish waste over natural seston (Sanz-Lazaro \& Sanchez-Jerez 2017).

\section{CONCLUSIONS}

The potential mussel harvest and nutrient removal was shown to depend on the food fluxes for 10 selected sites in the model. One mussel farm (36 ha) can potentially remove $17-31 \%$ of released nutrients from a nearby fish farm. Hence, several mussel farms would be needed to fully compensate for the additional nutrient inputs caused by a fish farm. Nutrient transports to sensitive areas and positive and negative environmental effects of mussel farms were also estimated for the same 10 sites. The combination of potential nutrient removal, nutrient transports and environmental effects were used as input to site selection of mussel mitigation cultures. Model results suggested that mussel farms located either inside or a few $\mathrm{km}$ outside the coastal area receiving the highest nutrient inputs from the fish farm were the most optimal with respect to environmental effects and nutrient compensation of fish farms. The site selection of fish and mussel farms needs to be integrated into local marine spatial planning, where environmental impacts and conflicts with other marine uses are considered. However, the weighting between different farm effects and other activities is a management decision depending on the given local conditions and sensitivity of the area. This study demonstrates that modeling can be used to support the management decision and provide the needed data on far-field and local effects from integrated aquaculture.

Acknowledgements. The present study received funding from BONUS OPTIMUS and BONUS BASMATI (Art 185), funded jointly by the EU, the Innovation Fund Denmark and the German Ministry for Education and Science (BMBF).

\section{LITERATURE CITED}

Bacher C, Gangnery A (2006) Use of dynamic energy budget and individual based models to simulate the dynamics of cultivated oyster populations. J Sea Res 56: 140-155

Berg P, Poulsen JW (2012) Implementation details for HBM. DMI Tech Rep 12-11. Danish Meteorological Institute, Copenhagen

*Bonsdorff E, Blomqvist EM, Mattila J, Norkko A (1997) Coastal eutrophication: causes, consequences and perspectives in the Archipelago areas of the northern Baltic Sea. Estuar Coast Shelf Sci 44:63-72

*Bostock J, McAndrew B, Richards R, Jauncey K and others (2010) Aquaculture: global status and trends. Philos Trans R Soc B 365:2897-2912

Buer AL, Maar M, Nepf M, Friedland R and others (2020) Potential and feasibility of Mytilus spp. farming along a salinity gradient. Frontiers Mar Sci 7:371

Carlsson MS, Holmer M, Petersen JK (2009) Seasonal and spatial variations of benthic impacts of mussel longline farming in a eutrophic Danish fjord, Limfjorden. J Shellfish Res 28:791-801

Carlsson MS, Engström P, Lindahl O, Ljungqvist L, Petersen JK, Svanberg L, Holmer M (2012) Effects of mussel farms on the benthic nitrogen cycle on the Swedish west coast. 
Aquacult Environ Interact 2:177-191

Carstensen J, Conley DJ, Henriksen P (2004) Frequency, composition, and causes of summer phytoplankton blooms in a shallow coastal ecosystem, the Kattegat. Limnol Oceanogr 49:191-201

Chopin T, Cooper JA, Reid G, Cross S, Moore C (2012) Open-water integrated multi-trophic aquaculture: environmental biomitigation and economic diversification of fed aquaculture by extractive aquaculture. Rev Aquacult 4:209-220

Christensen PB, Rysgaard S, Sloth NP, Dalsgaard T, Schwærter S (2000) Sediment mineralization, nutrient fluxes, denitrification and dissimilatory nitrate reduction to ammonium in an estuarine fjord with sea cage trout farms. Aquat Microb Ecol 21:73-84

Conley DJ, Kaas H, Møhlenberg F, Rasmussen B, Windolf J (2000) Characteristics of Danish estuaries. Estuaries 23: 820-837

Conley DJ, Carstensen J, Ærtebjerg G, Christensen PB, Dalsgaard T, Hansen JLS, Josefson AB (2007) Long-term changes and impacts of hypoxia in Danish coastal waters. Ecol Appl 17:S165-S184

* Cranford PJ, Reid GK, Robinson SMC (2013) Open water integrated multi-trophic aquaculture: constraints on the effectiveness of mussels as an organic extractive component. Aquacult Environ Interact 4:163-173

* Cranford PJ, Duarte P, Robinson SMC, Fernández-Reiriz MJ, Labarta U (2014) Suspended particulate matter depletion and flow modification inside mussel (Mytilus galloprovincialis) culture rafts in the Ría de Betanzos, Spain. J Exp Mar Biol Ecol 452:70-81

*Dalsgaard T, Krause-Jensen D (2006) Monitoring nutrient release from fish farms with macroalgal and phytoplankton bioassays. Aquaculture 256:302-310

Dalsgaard AJT, Pedersen PB (2016) Produktionsbidrag og dambrugsmodel: manual og modelforudsæetninger. DTU Aqua rapport:309-2016. DTU Aqua, Hirsthals

Duarte CM, Holmer M, Olsen Y, Soto D and others (2009) Will the oceans help feed humanity? Bioscience 59: 967-976

EIONET (2019) DK article 17 Report 2013-18_FINAL. http:// cdr.eionet.europa.eu/dk/eu/art17/envxwjjpq

FAO (2016) The state of world fisheries and aquaculture 2016. Contributing to food security and nutrition for all. FAO, Rome

Filgueira R, Guyondet T, Reid GK, Grant J, Cranford PJ (2017) Vertical particle fluxes dominate integrated multi-trophic aquaculture (IMTA) sites: implications for shellfish-finfish synergy. Aquacult Environ Interact 9: $127-143$

Grant J, Bacher C, Cranford PJ, Guyondet T, Carreau M (2008) A spatially explicit ecosystem model of seston depletion in dense mussel culture. J Mar Syst 73:155-168

HELCOM (2007) HELCOM Baltic Sea Action Plan. HELCOM Ministerial Meeting, Krakow, Poland, 15 Nov. 2007. HELCOM, Helsinki

HELCOM (2013) Summary report on the development of revised Maximum Allowable Input (MAI) and updated Country Allocated Reduction Targets (CART) of the Baltic Sea Plan. HELCOM, Helsinki

HELCOM (2018) State of the Baltic Sea - second HELCOM holistic assessment 2011-2016. Baltic Sea Environment Proceedings 155. https://helcom.fi/baltic-seatrends/holistic-assessments/state-of-the-baltic-sea-2018/ reports-and-materials/
Holbach A, Maar M, Timmermann K, Taylor D (2020) A spatial model for nutrient mitigation potential of blue mussel farms in the western Baltic Sea. Sci Tot Environ 736:139624

*Holmer M, Ahrensberg N, Jørgensen NP (2003) Impacts of mussel dredging on sediment phosphorus dynamics in a eutrophic Danish fjord. Chem Ecol 19:343-361

* Holmer M, Thorsen SW, Carlsson MS, Kjerulf PJ (2015) Pelagic and benthic nutrient regeneration processes in mussel cultures (Mytilus edulis) in a eutrophic coastal area (Skive Fjord, Denmark). Estuaries Coasts 38:1629-1641

Irisarri J, Fernandez-Reiriz MJ, Robinson SMC, Cranford PJ, Labarta U (2013) Absorption efficiency of mussels Mytilus edulis and Mytilus galloprovincialis cultured under integrated multi-trophic aquaculture conditions in the Bay of Fundy (Canada) and Ria Ares-Betanzos (Spain). Aquaculture 388-391:182-192

* Irisarri J, Fernández-Reiriz MJ, Labarta U, Cranford PJ, Robinson SMC (2015) Availability and utilization of waste fish feed by mussels Mytilus edulis in a commercial integrated multi-trophic aquaculture (IMTA) system: a multiindicator assessment approach. Ecol Indic 48:673-686

Kaas H, Birkeland MJ, Møhlenberg F (2017) Modellering af lokaliteter til havbrug. Vurdering af miljøeffekter. Standard havbrug A i havbrugszone A. Rapport til NaturErhvervstyrelsen. DHI, Hørsholm

Kooijman SALM (2010) Dynamic energy and mass budgets in biological systems. Cambridge University Press, Cambridge

Kotta J, Futter M, Kaasik A, Liversage K and others (2020) Cleaning up seas using blue growth initiatives: mussel farming for eutrophication control in the Baltic Sea. Sci Total Environ 709:136144

Krause-Jensen D, Middelboe AL, Carstensen J, Dahl K (2007) Spatial patterns of macroalgal abundance in relation to eutrophication. Mar Biol 152:25-36

* Lander TR, Robinson SMC, MacDonald BA, Martin JD (2013) Characterization of the suspended organic particles released from salmon farms and their potential as a food supply for the suspension feeder, Mytilus edulis in integrated multi-trophic aquaculture (IMTA) systems. Aquaculture 406-407:160-171

* Larsen J, Mohn C, Pastor A, Maar M (2020) A versatile marine modelling tool applied to arctic, temperate and tropical waters. PLOS ONE 15:e0231193

* Lester SE, Stevens JM, Gentry RR, Kappel CV and others (2018) Marine spatial planning makes room for offshore aquaculture in crowded coastal waters. Nat Commun 9:945

* Longdill PC, Healy TR, Black KP (2008) An integrated GIS approach for sustainable aquaculture management area site selection. Ocean Coast Manag 51:612-624

Lorrain A, Paulet YM, Chauvaud L, Dunbar R, Mucciarone D, Fontugne $M(2004) \delta^{13} \mathrm{C}$ variation in scallop shells: increasing metabolic carbon contribution with body size? Geochim Cosmochim Acta 68:3509-3519

₹ Maar M, Bolding K, Petersen JK, Hansen JLS, Timmermann $\mathrm{K}$ (2009) Local effects of blue mussels around turbine foundations in an ecosystem model of Nysted off-shore wind farm, Denmark. J Sea Res 62:159-174

* Maar M, Møller EF, Larsen J, Madsen KS and others (2011) Ecosystem modelling across a salinity gradient from the North Sea to the Baltic Sea. Ecol Model 222:1696-1711

Maar M, Saurel C, Landes A, Dolmer P, Petersen JK (2015) Growth potential of blue mussels ( $M$. edulis) exposed to different salinities evaluated by a Dynamic Energy Budget model. J Mar Syst 148:48-55 
Maar M, Markager S, Madsen KS, Windolf J, Lyngsgaard MM, Andersen HE, Møller EF (2016) The importance of local versus external nutrient loads for $\mathrm{Chl} a$ and primary production in the Western Baltic Sea. Ecol Model 320: 258-272

Maar M, Larsen J, Dahl K, Riemann B (2018a) Modelling the environmental impacts of future offshore fish farms in the inner Danish waters. Aquacult Environ Interact 10:115-133

Maar M, Larsen MM, Tørring D, Petersen JK (2018b) Bioaccumulation of metals $(\mathrm{Cd}, \mathrm{Cu}, \mathrm{Ni}, \mathrm{Pb}$ and $\mathrm{Zn})$ in suspended cultures of blue mussels exposed to different environmental conditions. Estuar Coast Shelf Sci 201:185-197

Mazur NA, Curtis AL (2008) Understanding community perceptions of aquaculture: lessons from Australia. Aquacult Int 16:601-621

Neumann T (2000) Towards a 3D-ecosystem model of the Baltic Sea. J Mar Syst 25:405-419

Nielsen P, Saurel C, Dalsgaard AJT (2015) Samtidigt opdræt af blåmuslinger og tang i forbindelse med havbrug. Rapport 297-2015. DTU Aqua, Charlottenlund

Nielsen P, Cranford PJ, Maar M, Petersen JK (2016) Magnitude, spatial scale and optimization of ecosystem services from a nutrient extraction mussel farm in the eutrophic Skive Fjord, Denmark. Aquacult Environ Interact 8:311-329

Nizzoli D, Welsh DT, Viaroli P (2011) Seasonal nitrogen and phosphorus dynamics during benthic clam and suspended mussel cultivation. Mar Pollut Bull 62:1276-1287

Petersen LK, Stybel N (2019) Local acceptance of mussel cultivation in the Baltic Sea. Conference paper Aquaculture Europe 7-10 Oct 2019, Berlin, Germany

* Petersen JK, Nielsen TG, van Duren L, Maar M (2008) Depletion of plankton in a raft culture of Mytilus galloprovincialis in Ría de Vigo, NW Spain. I. Phytoplankton. Aquat Biol 4:113-125

Petersen JK, Hasler B, Timmermann K, Nielsen P, Tørring DB, Larsen MM, Holmer M (2014) Mussels as a tool for mitigation in the marine environment. Mar Pollut Bull 82:137-143

Petersen JK, Holmer M, Termansen M, Hasler B (2019a) Nutrient extraction through bivalves. In: Smaal A, Ferreira J, Grant J, Petersen J, Strand Ø (eds) Goods and services of marine bivalves. Springer, Cham, p 179-208

Petersen JK, Loo LO, Taylor D (2019b) Evaluating chlorophyll depletion in mitigation mussel cultivation at multiple scales. Aquacult Environ Interact 11:263-278

* Petersen ME, Maar M, Larsen J, Møller EF, Hansen PJ (2017) Trophic cascades of bottom-up and top-down forcing on nutrients and plankton in the Kattegat, evaluated by modelling. J Mar Syst 169:25-39

Reid GK, Liutkus M, Robinson SMC, Chopin TR and others (2009) A review of the biophysical properties of salmonid faeces: implications for aquaculture waste dispersal models and integrated multi-trophic aquaculture. Aquacult Res 40:257-273

Riisgård HU, Bøttiger L, Pleissner D (2012) Effect of salinity on growth of mussels, Mytilus edulis, with special reference

Editorial responsibility: Dror Angel,

Haifa, Israel to the Great Belt (Denmark). Open J Mar Sci 2:167-176

* Riisgård HU, Lundgreen K, Pleissner D (2015) Environmental factors and seasonal variation in density of mussel larvae (Mytilus edulis) in Danish waters. Open J Mar Sci 5: 280-289

Sanchez-Jerez P, Karakassis I, Massa F, Fezzardi D and others (2016) Aquaculture's struggle for space: the need for coastal spatial planning and the potential benefits of Allocated Zones for Aquaculture (AZAs) to avoid conflict and promote sustainability. Aquacult Environ Interact 8: 41-54

Sanz-Lazaro C, Sanchez-Jerez P (2017) Mussels do not directly assimilate fish farm wastes: shifting the rationale of integrated multi-trophic aquaculture to a broader scale. J Environ Manag 201:82-88

Schröder T, Stank J, Schernewski G, Krost P (2014) The impact of a mussel farm on water transparency in the Kiel Fjord. Ocean Coast Manag 101:42-52

Taylor D, Saurel C, Nielsen P, Petersen JK (2019) Production characteristics and optimization of mitigation mussel culture. Front Mar Sci 6:698

* Timmermann K, Maar M, Bolding K, Larsen J, Windolf J, Nielsen P, Petersen JK (2019) Mussel production as a nutrient mitigation tool for improving marine water quality. Aquacult Environ Interact 11:191-204

*Tovar A, Moreno C, Mánuel-Vez MP, García-Vargas M (2000) Environmental impacts of intensive aquaculture in marine waters. Water Res 34:334-342

Valdemarsen T, Hansen PK, Ervik A, Bannister RJ (2015) Impact of deep-water fish farms on benthic macrofauna communities under different hydrodynamic conditions. Mar Pollut Bull 101:776-783

van der Veer HW, Cardoso JFMF, van der Meer J (2006) The estimation of DEB parameters for various Northeast Atlantic bivalve species. J Sea Res 56:107-124

V Veidemane K, Ruskule A, Sprukta S (2017) Development of a maritime spatial plan - the Latvian recipe. Baltic SCOPE project report. www.balticscope.eu/content/ uploads/2015/07/LV-recipe_EN_web.pdf

* von Thenen M, Maar M, Hansen HS, Friedland R, Schiele KS (2020) Applying a combined geospatial and farm scale model to identify suitable locations for mussel farming. Mar Poll Bull 156:111254

*Wan Z, She J, Maar M, Jonasson L, Baasch-Larsen J (2012) Assessment of a physical-biogeochemical coupled model system for operational service in the Baltic Sea. Ocean Sci 8:683-701

*Wild-Allen K, Herzfeld M, Thompson PA, Rosebrock U, Parslow J, Volkman JK (2010) Applied coastal biogeochemical modelling to quantify the environmental impact of fish farm nutrients and inform managers. J Mar Syst 81:134-147

₹ Zbawicka M, Sańko T, Strand J, Wenne R (2014) New SNP markers reveal largely concordant clinal variation across the hybrid zone between Mytilus spp. in the Baltic Sea. Aquat Biol 21:25-36

Submitted: January 14, 2020; Accepted: May 4, 2020

Proofs received from author(s): August 3, 2020 